\title{
Novel index for quantification of ecosystem effects of fishing as removal of secondary production
}

\author{
Simone Libralato ${ }^{1, *}$, Marta Coll $^{2}$, Sergi Tudela ${ }^{3}$, Isabel Palomera ${ }^{2}$, Fabio Pranovi ${ }^{4}$ \\ ${ }^{1}$ Istituto Nazionale di Oceanografia e di Geofisica Sperimentale (OGS), Borgo Grotta Gigante 42/c, 34010, Sgonico (TS), Italy \\ ${ }^{2}$ Institut de Ciènces del Mar, CMIMA-CSIC, Passeig Marítim de la Barceloneta, 37-49, 08003 Barcelona, Spain \\ ${ }^{3}$ World Wildlife Fund, Mediterranean Programme Office, Carrer Canuda, 37, 08002 Barcelona, Spain \\ ${ }^{4}$ Dipartimento di Scienze Ambientali, Università Ca' Foscari, 2137 Dorsoduro, 30123 Venezia, Italy
}

\begin{abstract}
Exploited ecosystems are characterised by exports of secondary production from each fished trophic level that reduce the energy available for upper levels at the ecosystem scale, thus impinging on overall secondary production. Depletion in secondary production is proposed here as a proxy for quantifying the ecosystem effects of fishing. Theoretical analysis of trophic web interactions permits the quantification of the 'loss in production' and provides an ecological basis for defining a new synthetic index (L index) that takes into account both ecosystem properties (primary production and transfer efficiency) and features of fishing activities (trophic level of catches and primary production required). Quantitative meta-analysis of ecological models, representing 51 exploited ecosystems previously classified as overexploited or sustainably exploited, allows the association of a probability of the ecosystem being sustainably fished with each index value. Moreover, by fixing the reference level for this probability, the index provides a basis for estimating the maximum allowable catches. The L index is applied here to several ecosystems worldwide using landings data and ecological models, providing quantification of the disruption of energy flows for ecosystems subjected to different types and levels of fishing pressure. Its application to outputs of calibrated dynamic models enables the evaluation of sustainability of fisheries in past and future scenarios of alternative fisheries management policies. Results highlight the usefulness of this index for quantifying the impacts of fishing and providing directional advice for fisheries management. Thus, the L index may be used to support ecosystem-based management of fisheries.
\end{abstract}

KEY WORDS: Fishing impacts · Ecosystem functioning · Loss in production · Primary production required · Trophic level · Overfishing · Ecosystem-based fisheries management

\section{INTRODUCTION}

Many fisheries are unsustainable. Overfishing evaluated through historical data (Jackson et al. 2001, Lotze et al. 2006), the decreasing trend of catch per unit (CPUE) effort for predatory fishes (Myers \& Worm 2003) and the fishing down food web effect (Pauly et al. 1998a) are evidence of fishing impacts at the global scale. Indirect effects of fishing affect non-target components of the trophic web, from top predators (Springer et al. 2003) to benthic species (Jennings \& Kaiser 1998). Fishing impacts propagate along trophic webs through cascading effects (Pace et al. 1999), affecting both the structure and functioning of ecosystems (Murawski 2000) and increasing the need for holistic approaches to fisheries (Pauly et al. 2002). Consequently, an increasing need for ecosys- tem-based fishery management is being recognised by governmental entities, e.g. the European Community (2002), Canada's Oceans Act (Department of Justice Canada 1996) and the US Commission on Ocean Policy (2004).

The current challenge is to ensure a profitable yield, simultaneously accounting for dramatic changes in population abundances, biodiversity decrease and habitat degradation (Larkin 1996). Within this framework, scientists are searching for robust and quantitative indicators that will prove useful for communicating with stakeholders, monitoring, and assessing and adjusting policies towards defined management objectives (Daan et al. 2005). While several indicators have been proposed to date, very few seem to match all the criteria simultaneously (Rochet \& Trenkel 2003). 
In this work, the loss in secondary production due to exploitation is used as a proxy for quantifying the ecosystem impacts of fishing. Its usefulness as an indicator for the ecosystem-based management of fisheries is evaluated through its extensive application.

\section{Production as an indicator in the context of the ecosystem-based management}

Using production as an ecosystem indicator is not new. Production integrates a set of fundamental ecological processes and is an indicator of ecosystem functioning (Tilman et al. 1997). Moreover, given the positive linear function between production and biodiversity at a regional scale as well as the bi-directionality of their relationship (Worm \& Duffy 2003), a decrease in production might represent a threat to biodiversity and increase the risk of local extinction (Myers \& Worm 2005).

Production has also been used in the fishery context to develop ecosystem-based references for fishery management (Bundy et al. 2005). Primary production required to sustain the fishery (PPR) (Pauly \& Christensen 1995) enabled quantification of the fishing pressure on ecosystems at a global scale. Tudela et al. (2005) suggested the coupling of PPR over actual primary production (PP) with the mean trophic level of the catch $\left(\mathrm{TL}_{\mathrm{c}}\right)$ to capture ecosystem effects of fishing.

In this study, theoretical analysis of trophic web interactions allows us to quantify the 'loss in secondary production' due to fishing that results as a function of catches (expressed in terms of PPR), $\mathrm{TL}_{\mathrm{C}}$, PP and transfer efficiency (TE) within the food web. Given the importance of production in determining ecosystem functioning (Tilman et al. 1997), the loss in secondary production due to fishing could be used as a comprehensive measure of alterations caused by exploitation. It could represent a trait summarizing all the effects that fishing might produce at the ecosystem level (sensu Murawski 2000), despite different system alterations produced by the coupling of different direct fishing impacts (Tittensor et al. 2006) and the complexity of ecosystem responses (Worm \& Duffy 2003).

Estimation of the loss in secondary production from outputs of models representing well-studied ecosystems a priori classified as 'overfished' or 'sustainably fished' (Murawski 2000) enables us to associate a probability of the ecosystem belonging to a sustainably fished situation with each loss value. Applying the $\mathrm{L}$ index to different exploitation data, we infer the sustainability of fisheries for various exploited ecosystems worldwide and compare results with published analyses done on the basis of population and community data. Although our application takes advantage of data organized in Ecopath with Ecosim (EwE) food web models (Christensen \& Walters 2004), the L index is independent from EwE. It can be applied to other modelling approaches and landings data, provided that PPR, PP, TE and $\mathrm{TL}_{\mathrm{c}}$ can be estimated. Fixing desirable target probabilities, we calculate the maximum sustainable catches (Tudela et al. 2005) that might provide a basis for ecosystem-based management of fisheries. In addition, application of the $\mathrm{L}$ index to outputs of dynamic models (Walters et al. 2005) enables us to estimate the sustainability of fisheries over time and to evaluate alternative management options.

\section{Loss in secondary production as a proxy for quantifying effects of fishing}

A common feature of exploited ecosystems is the export of a portion of secondary production from each fished trophic level, the type and strength of the impact notwithstanding. Despite the presence of compensatory effects within populations and communities (Walters \& Martell 2004), this export at any given trophic level reduces the energy amount available for upper levels at ecosystem scale.

Loss in secondary production due to fisheries export can be derived theoretically by representing any complex food web as an equivalent linear food chain linking production $\left(\mathrm{P}_{\mathrm{TL}}\right)$ at each trophic level (TL) by means of an average TE (Teramoto 1993). TL is here intended as a fractional value and defined as the average TL of prey weighted by their proportion in the diet of the predator (Pauly et al. 1998a, Stergiou \& Karpouzi 2002). TE summarizes all the inefficiencies (due to respiration, excretion, and natural mortality) present at each step of the trophic chain and it is obtained as the ratio between the production of 2 adjacent TLs (Lindeman 1942, Pauly \& Christensen 1995).

Under the assumptions that the system is in equilibrium and all transfers in the trophic chain are characterized by a single $\mathrm{TE}$, it is possible to estimate $\mathrm{P}_{\mathrm{TL}}$ given the production of the TL $=1\left(\mathrm{P}_{1}\right.$, autotrophic production and detritus production by the trophic web) by means of the following equation (Lalli \& Parsons 1993):

$$
\mathrm{P}_{\mathrm{TL}}=\mathrm{P}_{1} \cdot \mathrm{TE}^{\mathrm{TL}-1}
$$

Using Eq. (1) it is possible to estimate the theoretical loss of production at each trophic level caused by harvesting a quantity $\mathrm{Y}_{\mathrm{C}}$ at $\mathrm{TL}_{\mathrm{C}}$. As an example, harvesting $\mathrm{Y}_{2}$ at $\mathrm{TL}_{\mathrm{C}}=2$ results in the following production at each trophic level:

$$
\begin{gathered}
\mathrm{P}_{2}=\mathrm{P}_{1} \cdot \mathrm{TE} \\
\mathrm{P}_{3}=\left(\mathrm{P}_{1} \cdot \mathrm{TE}-\mathrm{Y}_{2}\right) \cdot \mathrm{TE} \\
\mathrm{P}_{4}=\left(\mathrm{P}_{1} \cdot \mathrm{TE}-\mathrm{Y}_{2}\right) \cdot \mathrm{TE}^{2} \\
\cdots \\
\mathrm{P}_{\mathrm{TL}}=\left(\mathrm{P}_{1} \cdot \mathrm{TE}-\mathrm{Y}_{2}\right) \cdot \mathrm{TE}^{\mathrm{TL}-2}=\mathrm{P}_{1} \cdot \mathrm{TE}^{\mathrm{TL}-1}-\mathrm{Y}_{2} \cdot \mathrm{TE}^{\mathrm{TL}-2}
\end{gathered}
$$


where negative terms represent indirect losses in secondary production at each TL $>2$. Analogously, harvesting a quantity $\mathrm{Y}_{\mathrm{C}}$ at a general $\mathrm{TL}_{\mathrm{C}}$ results in a theoretical decrease of production $(\Delta \mathrm{P})$ for each $\mathrm{TL}$, that is:

$$
\Delta \mathrm{P}_{\mathrm{TL}}=\mathrm{Y}_{\mathrm{C}} \cdot \mathrm{TE}^{\mathrm{TL}-\mathrm{TL}_{\mathrm{C}}}
$$

Total decrease in production along all the trophic levels $\left(\Delta \mathrm{P}_{\text {tot }}\right)$, due to the fishing at $\mathrm{TL}_{\mathrm{C}}$, can be estimated by summing losses $\left(\Delta \mathrm{P}_{\mathrm{TL}}\right)$ from $\mathrm{TL}_{\mathrm{C}}$ to the maximum $\mathrm{TL}$ of the trophic chain. Since there are small flows subjected to a high number of passages along the trophic chain, flows with very high TL exist, especially if cannibalism and cycling are considered (Baird \& Ulanowicz 1989). Therefore, it is mathematically convenient to sum over all possible TLs to infinity. This does not influence the results due to the decreasing contribution of high TLs to $\Delta \mathrm{P}_{\text {tot. }}$ In the continuous domain of TL $(\tau)$, estimation of the loss in secondary production would imply the solution of the following integral:

$$
\Delta \mathrm{P}_{\text {tot }}=\int_{\mathrm{TL}_{\mathrm{C}}}^{\infty} \mathrm{Y}_{\mathrm{C}} \cdot \mathrm{TE}^{\tau-\mathrm{TL}_{\mathrm{C}}} \mathrm{d} \tau
$$

Catches can be expressed in terms of PPR (Pauly \& Christensen 1995), thus accounting for the different amount of energy required for production at different TLs (from Eq. 1, $\mathrm{Y}_{\mathrm{C}}=\mathrm{PPR} \cdot \mathrm{TE}^{\mathrm{TL}_{\mathrm{c}}-1}$ ). Primary production can be used to normalize primary production required to sustain the fishery $\left(\% \mathrm{PPR}=\mathrm{PPR} / \mathrm{P}_{1}\right)$. Thus, the relative loss in production, here called the $\mathrm{L}$ index, is estimated by:

$\mathrm{L}=\int_{\mathrm{TL}_{\mathrm{C}}}^{\infty} \frac{\mathrm{PPR}}{\mathrm{P}_{1}} \cdot \mathrm{TE}^{\mathrm{TL}_{\mathrm{C}}-1} \cdot \mathrm{TE}^{\tau-\mathrm{TL}_{\mathrm{C}}} \mathrm{d} \tau=-\frac{\mathrm{PPR} \cdot \mathrm{TE}^{\mathrm{TL}_{\mathrm{C}}-1}}{\mathrm{P}_{1} \cdot \ln \mathrm{TE}}$

where the integral is solved considering that TE is by definition smaller than 1 (Lindeman 1942, Pauly \& Christensen 1995).

Losses are simply additive. Therefore, for multitarget fisheries, the total loss in production can be estimated by summing the contribution of each species (i) expressed in Eq. (5) over $m$ caught species (Fig. 1A), as in the following equation:

$$
\mathrm{L}=-\frac{1}{\mathrm{P}_{1} \cdot \ln \mathrm{TE}} \cdot \sum_{i}^{m}\left(\mathrm{PPR}_{i} \cdot \mathrm{TE}^{\mathrm{TL}_{i}-1}\right) \cong-\frac{\mathrm{PPR} \cdot \mathrm{TE}^{\mathrm{TL}_{\mathrm{C}}-1}}{\mathrm{P}_{1} \cdot \ln \mathrm{TE}}
$$

where $\mathrm{TL}_{c}$ is calculated by weighting the TL of the caught species by their proportion in the total catch and reflects the overall strategy of the fishery (Pauly et al. 1998a). For graphic representation and sensitivity analysis, it is convenient to approximate the L index by using total PPR and the $\mathrm{TL}_{\mathrm{c}}$ of the multispecies fishery as reported in the right side of Eq. (6), whereas the lefthand side is used to estimate the L index and its reference levels.

The total theoretical decrease in production with respect to the unexploited situation (Eq. 6) represents
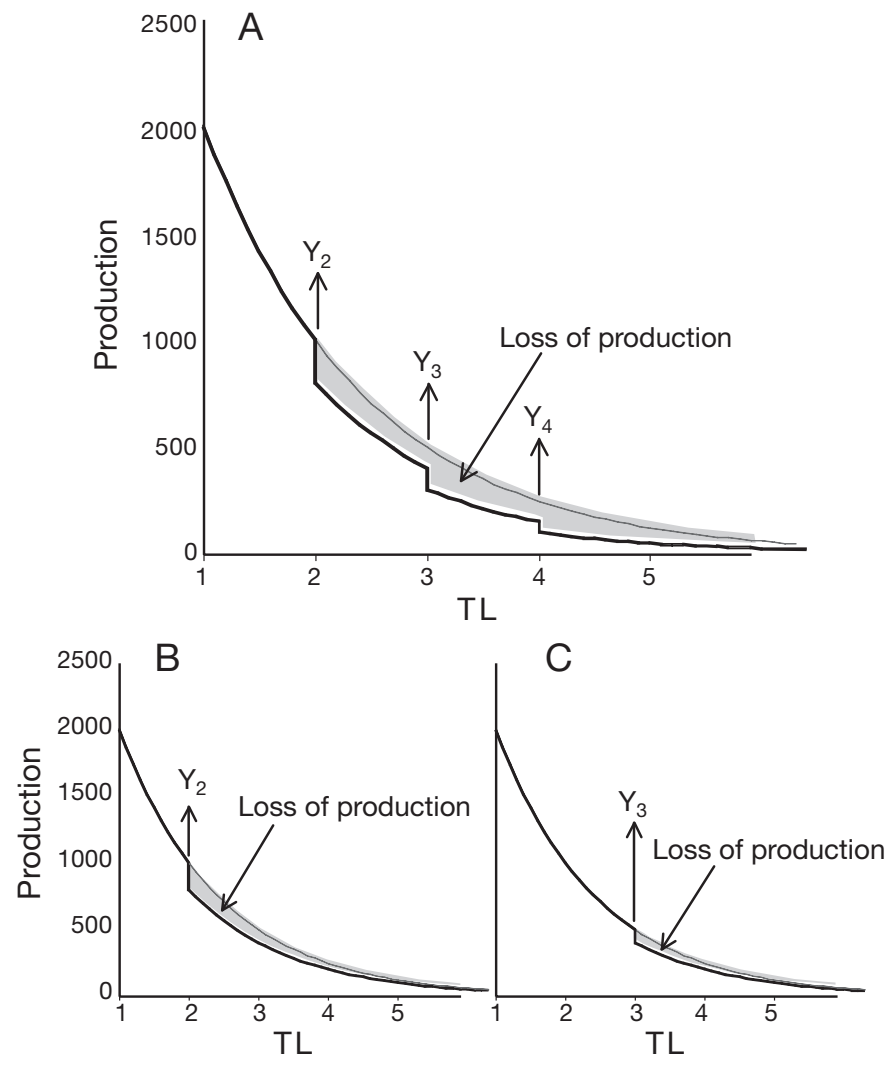

Fig. 1. Theoretical estimates of production at all trophic levels (TLs) when transfer efficiency (TE) is assumed constant for unfished ecosystems (thin grey line). Theoretical decrease in production at upper TLs is due to appropriation of part of the production at a different TL by the fisheries (thick black line). Catches $(\mathrm{Y})$ taken at different TLs are equivalent in terms of the primary production required to sustain the fishery (PPR). (A) The loss of production (shaded area) for multitarget fisheries (catches at TL 2, 3 and 4). (B,C) Comparing cases for landings coming respectively at TL 2 and 3, the greater loss in the production (shaded areas) for fishing at a lower TL is evident

the ecological costs of fishing at the $\mathrm{TL}_{\mathrm{c}}$. Ecosystems showing equal values of theoretical loss in production, i.e. the same L index value, would be considered equally depleted by fishing exploitation even if subjected to different fishing impacts and regimes.

Eq. (6) states that, for equivalent amount of catches expressed in PPR units, the relative loss in secondary production increases when TL of catches decreases since TE is always $<1$. This mathematical result is graphically represented in Fig. 1B,C, where the loss in production in the food web is higher when fishing occurs at lower TL, as well as when catches have the same amount of equivalent PPR. More importantly, this analytical result is in accordance with the negative effects of fishing down the food web that was evaluated at the global scale (Pauly et al. 1998a).

In order to explore the propagation of uncertainty of each of the input variables $\left(\mathrm{PPR}, \mathrm{P}_{1}, \mathrm{TE}\right.$ and $\mathrm{TL}_{\mathrm{c}}$ ) on the 
value of the L index, analytical and numerical sensitivity analyses were carried out, providing evidence of the high influence of $\mathrm{TL}_{\mathrm{c}}$ on the $\mathrm{L}$ index, of the moderate influence of TE and of relatively low and constant sensitivities of PPR and $\mathrm{P}_{1}$ (see Appendix 1).

Trophic web models can yield estimates of PPR and $\mathrm{P}_{1}$ based on the primary producers food chain only $\left(\mathrm{PPR}_{\mathrm{a}}\right.$ and $\mathrm{P}_{1}=\mathrm{PP}$ ) and also by including detrital production $\left(\mathrm{PPR}_{\mathrm{b}}\right.$ and $\mathrm{P}_{1}=\mathrm{PP}+$ flows to detritus $) . \mathrm{PPR}_{\mathrm{b}}$ should be preferred for its completeness. However, when using landings data, detrital flows might be difficult to quantify. Therefore, the index was applied using both $P P R_{a}$ and $P P R_{b}$ values and their respective normalizing factors for ecosystem models, while only $\mathrm{PPR}_{\mathrm{a}}$ and $\mathrm{PP}$ were used when applying the $\mathrm{L}$ index to landings data.

\section{MATERIALS AND METHODS}

Defining an ecosystem-based reference framework for fisheries management. Data regarding $\% P_{P R}$ and $\% \mathrm{PPR}_{\mathrm{b}}, \mathrm{TL}_{\mathrm{c}}$ and $\mathrm{TE}$ were obtained from a set of 91 ecosystem models previously constructed using the EwE software package (Christensen \& Walters 2004, www.ecopath.org), and representing ecosystems characterised by different fishing pressures. The ecosystems that were well-studied and had enough information available were evaluated with respect to their fishing pressure and categorised as overfished or sustainably fished ecosystems, based on the criteria proposed by Murawski (2000). According to these criteria, overfished ecosystems involve structural and functional degradation, associated with stock collapses and overall overexploitation of marine resources, whilst in sustainably fished ecosystems, main functioning and structure are preserved. Thus, the ecosystems studied here were given an overexploited status when cumulative fishing impacts manifested at least 1 overexploitation symptom (Murawski 2000). This was done using information obtained from published and unpublished sources, personal communication with experts and modellers of each ecosystem, and findings of previous analyses (Tudela et al. 2005). The available information allowed the classification of 51 models (29 as overexploited and 22 as sustainably exploited; Table 1), while 40 models remained unclassified (Table 2).

A meta-analysis of the 51 classified models was conducted in order to develop a probability measure of sustainability. The L index was estimated for each model using the right side of Eq. (6) and both \%PPR $\% \mathrm{PPR}_{\mathrm{b}} . \mathrm{L}_{1}$ and $\mathrm{L}_{2}$ are defined as values of the index estimated for the 29 models of overexploited ecosystems and the 22 sustainably fished ecosystems, respectively. The probability of an ecosystem being sustainably fished ( $\left.p_{\text {sust }}\right)$ was defined for any given value of $L$ as:

$$
\mathrm{p}_{\text {sust }}(\mathrm{L})=\frac{\mathrm{P}\left(\mathrm{L}_{2}>\mathrm{L}\right)}{\mathrm{P}\left(\mathrm{L}_{2}>\mathrm{L}\right)+\mathrm{P}\left(\mathrm{L}_{1}<\mathrm{L}\right)}
$$

where $\mathrm{P}\left(\mathrm{L}_{1}<\mathrm{L}\right)$ is the number of cases within Group 1 that have values of the index lower than a chosen value $\mathrm{L}$. For example, $\mathrm{L}_{50 \%}$ is the value of $\mathrm{L}$ that allows the proportion of overfished models with smaller values of $\mathrm{L}, \mathrm{P}\left(\mathrm{L}_{1}<\mathrm{L}\right)$, to be equal to the proportion of sustainably fished models having greater $\mathrm{L}$ values, $\mathrm{P}\left(\mathrm{L}_{2}>\right.$ $\mathrm{L})$, thus $\mathrm{P}\left(\mathrm{L}_{1}<\mathrm{L}\right)=\mathrm{P}\left(\mathrm{L}_{2}>\mathrm{L}\right)$ and $\mathrm{p}_{\text {sust }}(\mathrm{L})=50 \%$.

Therefore, for any given value of $\mathrm{L}$, the corresponding $\mathrm{p}_{\text {sust }}$ is estimated, providing values ranging from 0 to $100 \%$, useful for identifying operational reference points. Fixing any desired reference for sustainability of the fisheries on the basis of risk assumptions, $\mathrm{p}_{\text {sust }}=\mathrm{p}$, it is possible to back-estimate the corresponding reference value of the index $L=L_{p}$ that is linked with fishing pressure. In order to consider moderate and low risk of ecosystem overfishing, reference probabilities were set at $p_{\text {sust }}=75$ and $95 \%$ and the associated $\mathrm{L}_{75} \%$ and $\mathrm{L}_{95} \%$ were used to define an ecosystembased reference framework for fishery management.

Incorporating uncertainty in the reference framework. Confidence intervals for the identified relationship between $L$ values and $p_{\text {sust }}$ were derived through the application of the jackknife resampling method (Crowley 1992) as described in the following steps:

(1) Randomly extract a subset of $\mathrm{k}$ models from the original data set of $\mathrm{n}=51$ models, with $\mathrm{k}<\mathrm{n}$;

(2) For the randomly chosen subset, perform analyses using Eq. (7) for estimating $p_{\text {sust }}$ values for any $L$ within an appropriate range;

(3) Repeat the process $\mathrm{N}$ times, thus obtaining $\mathrm{N}$ independent estimates of $\mathrm{p}_{\text {sust }}$ for any $\mathrm{L}$.

Resampling was done by extracting a subset of $\mathrm{k}=45$ models guaranteeing approximately $1.8 \times 10^{7}$ different combinations among which $\mathrm{N}=500$ cases were randomly chosen. At the end of the above procedure, $\mathrm{N}$ values of $p_{\text {sust }}$ were synthetically obtained for any value of $\mathrm{L}$, thus providing estimates of confidence intervals for the relationship between $\mathrm{L}$ and $\mathrm{p}_{\text {sust }}$.

Applying the loss in secondary production to exploited systems. Suitability of the loss in secondary production for evaluating fishing pressure on ecosystems was assessed by applying the L index to different data: (1) mass-balance models, (2) calibrated dynamic ecosystem models, and (3) landings data sets.

(1) The $L$ index and $p_{\text {sust }}$ were estimated for models not used for defining reference values. Estimated $\mathrm{p}_{\text {sust }}$ levels provided evaluation of the sustainability of fisheries in the modelled ecosystems $\left(\mathrm{p}_{\text {sust }}<50 \%=\right.$ overexploited; $\mathrm{p}_{\text {sust }}>50 \%=$ sustainably fished) and results were evaluated in terms of coherence with partial information available.

(2) The L index was also estimated using outputs of 4 dynamic ecosystem models (Walters et al. 2005) 


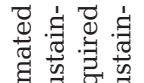

焉

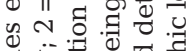

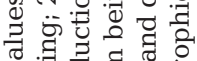
궁

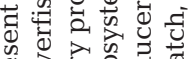

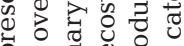
के जo 칠 5.

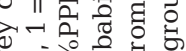

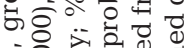
舟, 2.

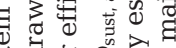

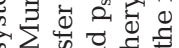
त . 웝 a

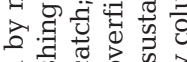
呵

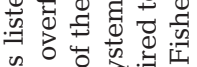
过 2 .

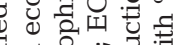

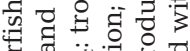
政记 융

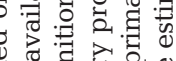

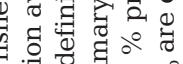
웡 乎 语 总讨 y 음

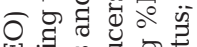

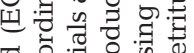

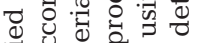

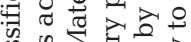

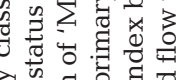
s)

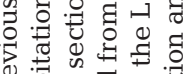

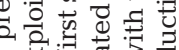
숭

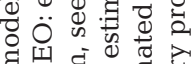
웡

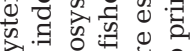
1.

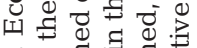

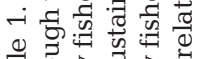
옹 훙

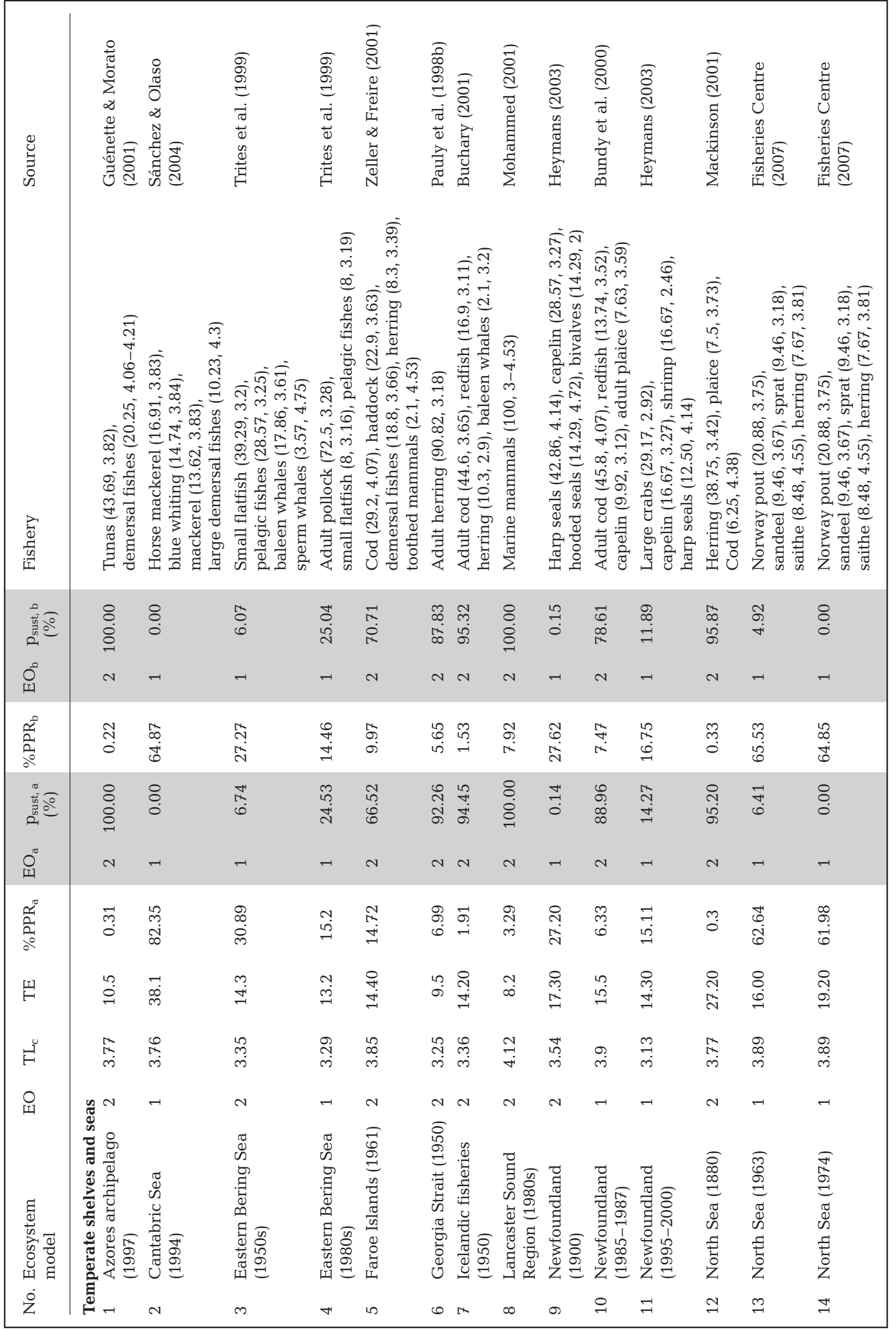




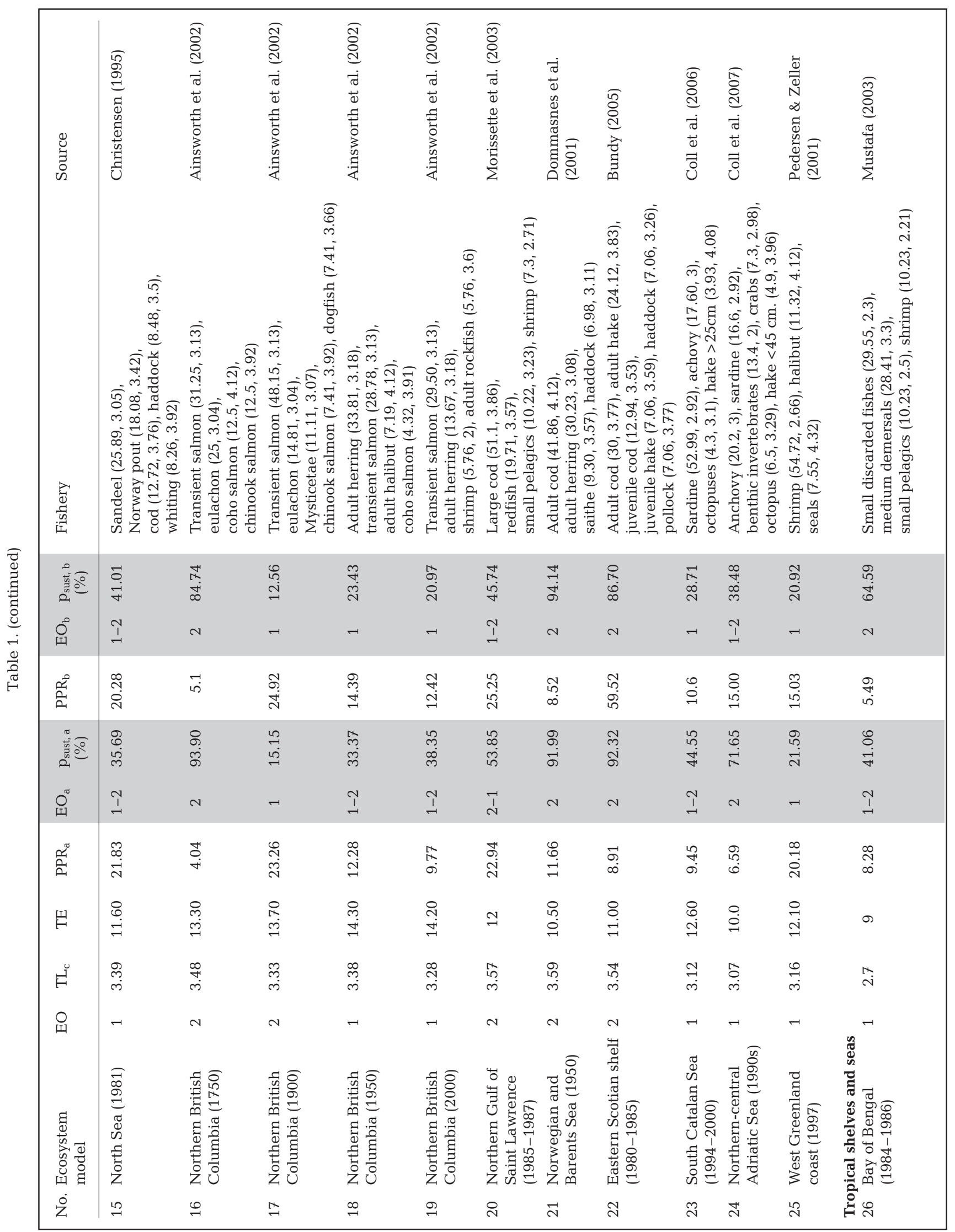




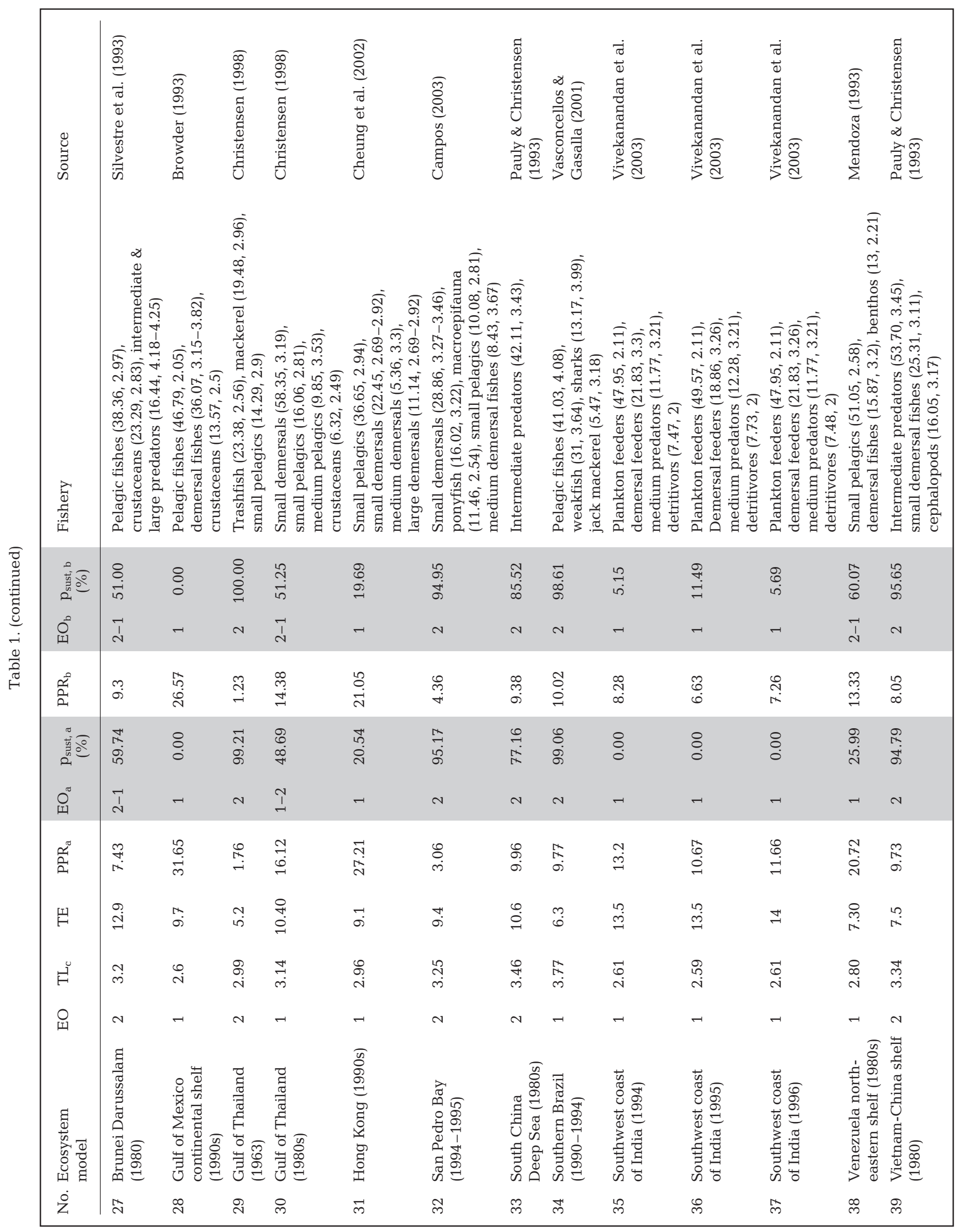




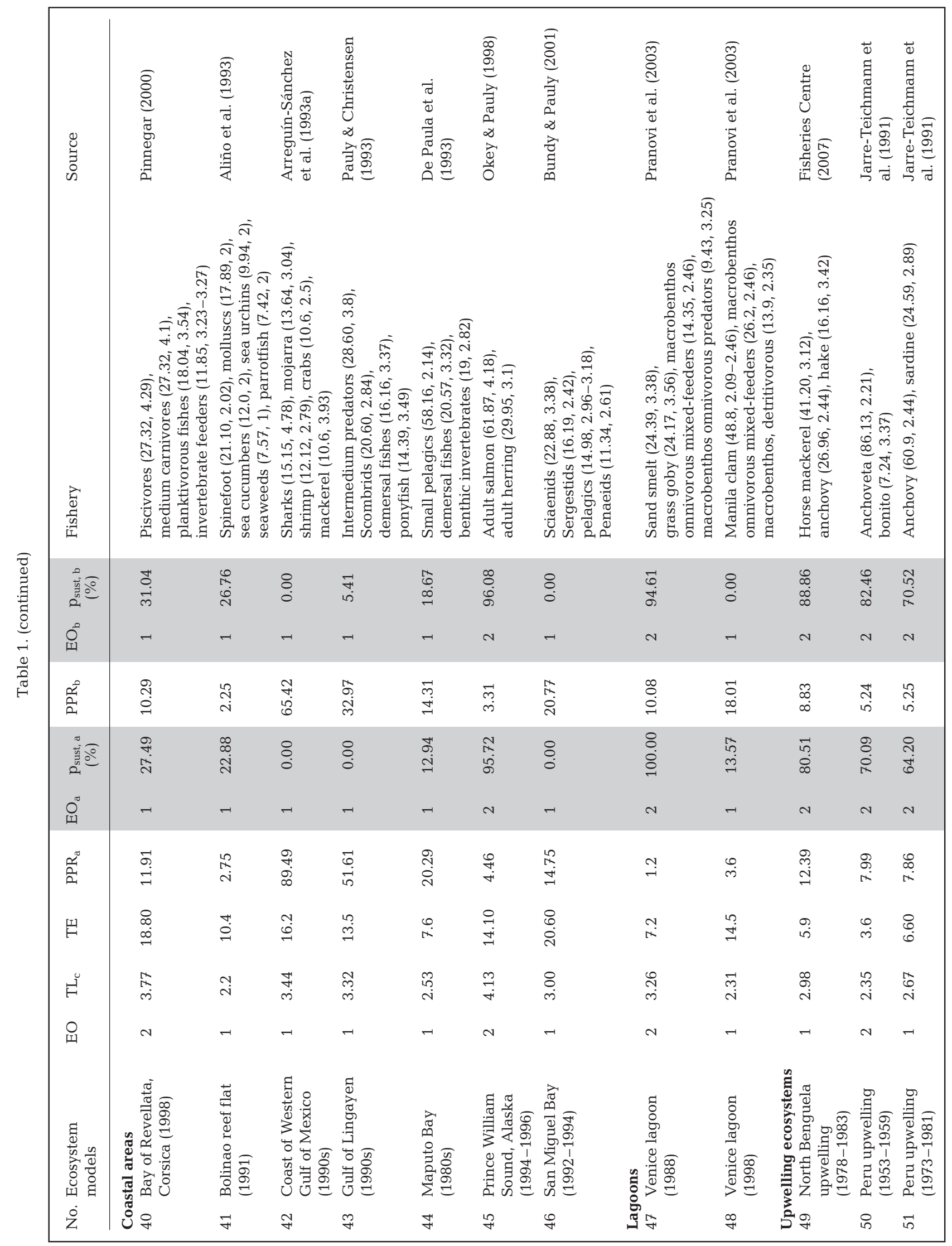




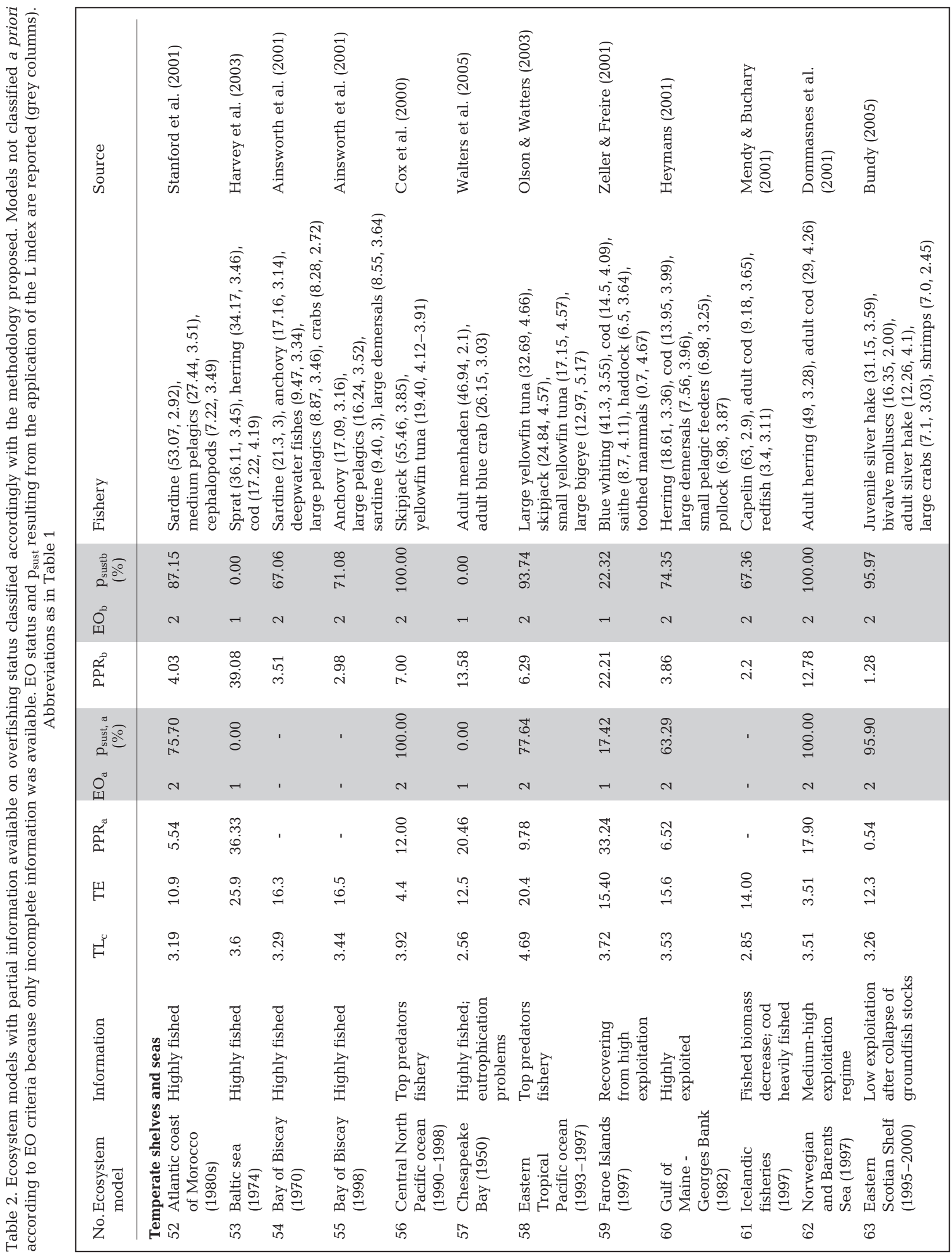




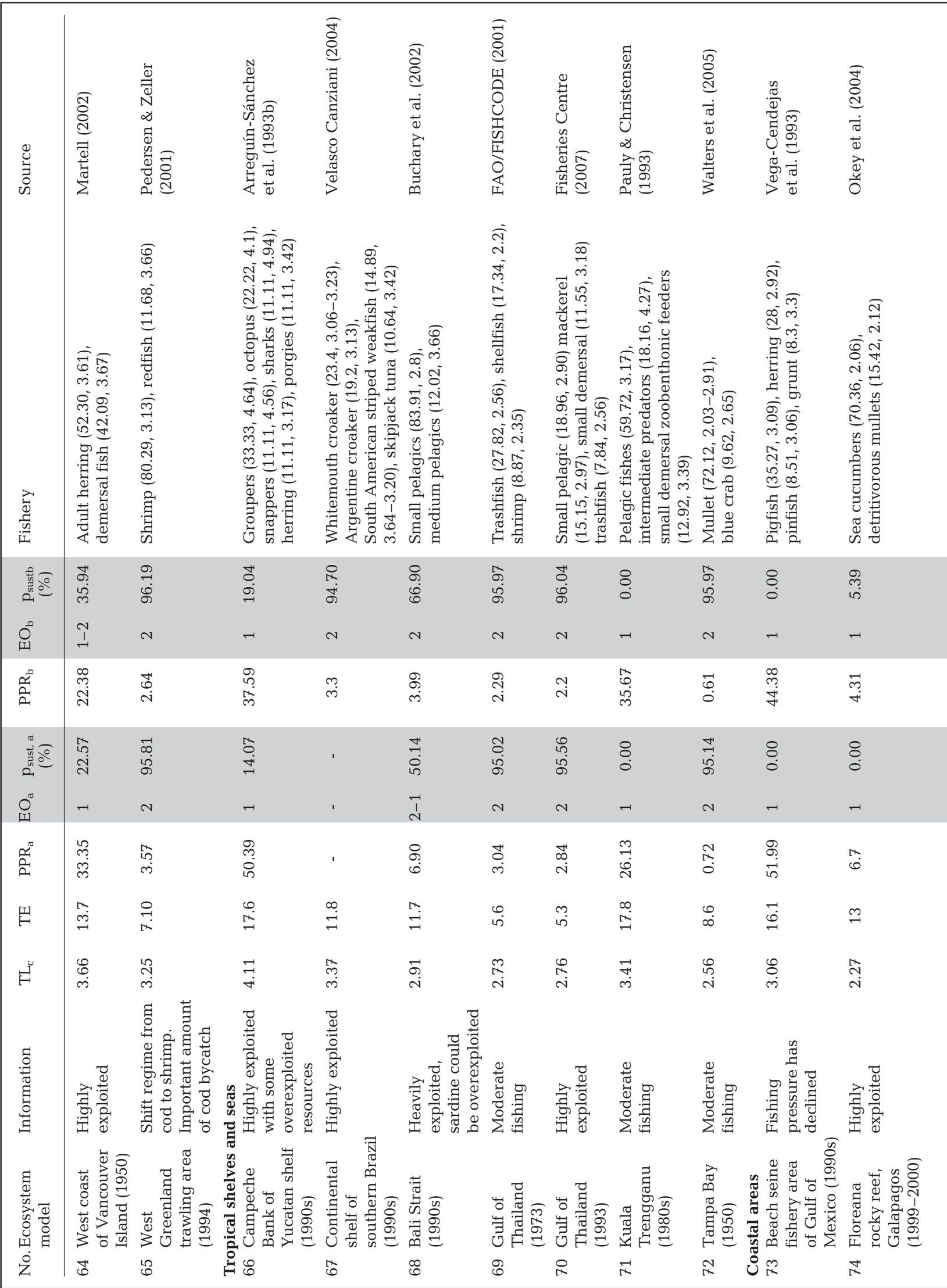




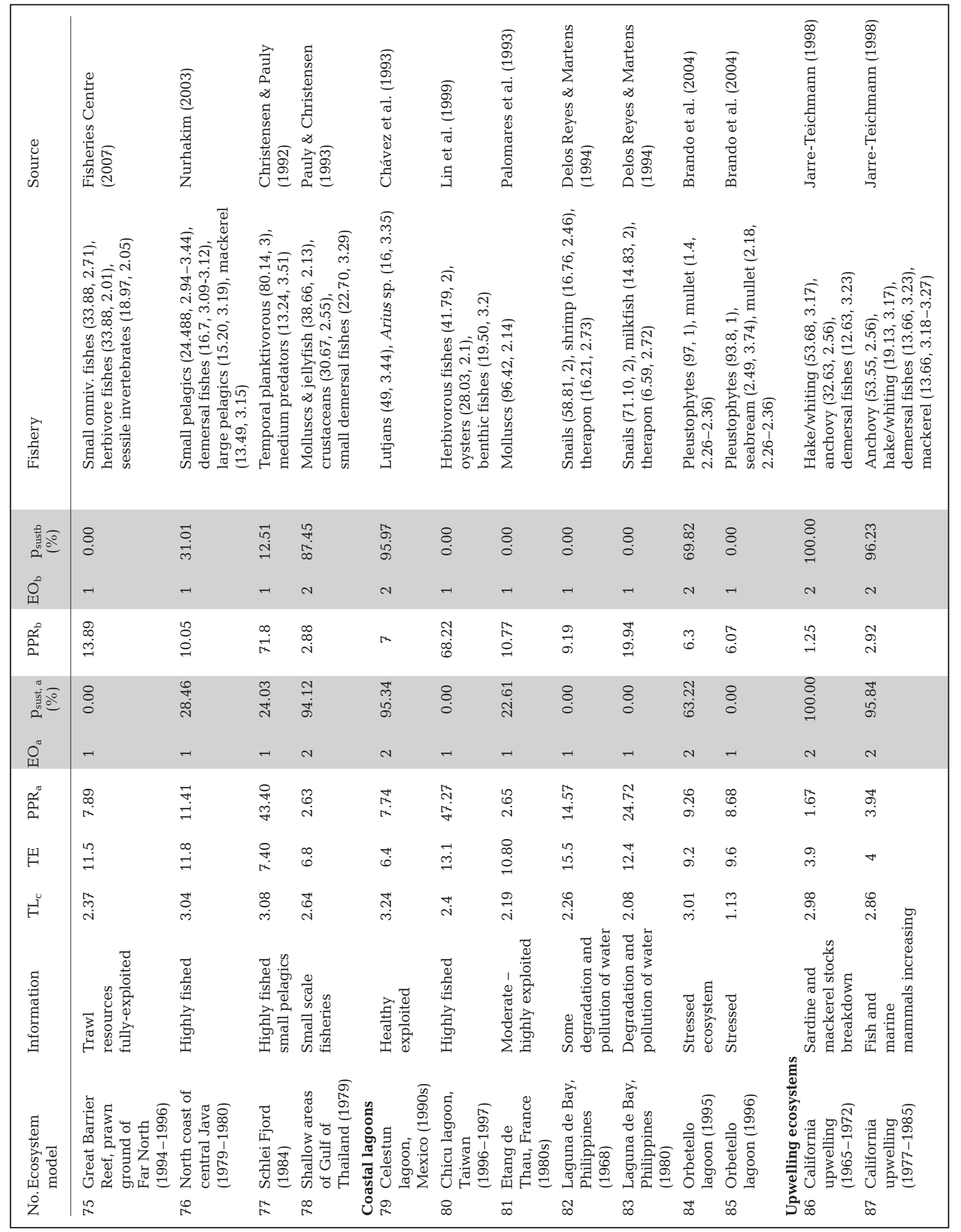




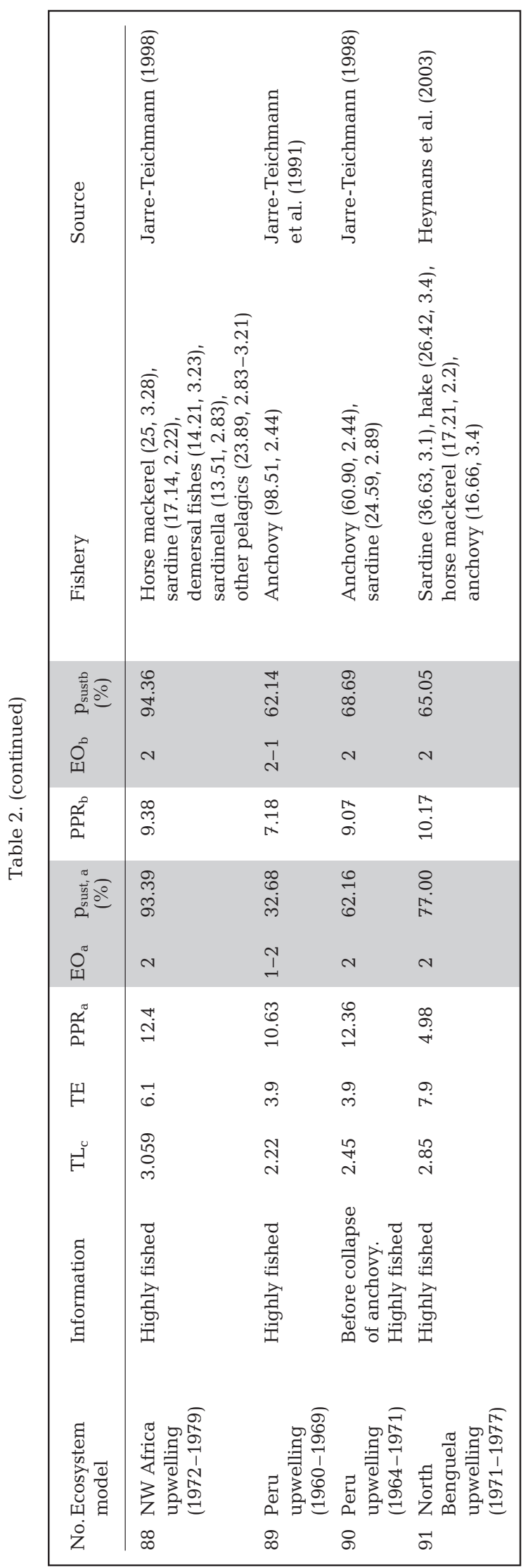

representing the North Sea, the Western Vancouver Island coast, the Southern Benguela and the Eastern Tropical Pacific. These models are provided with time series of biological data, vulnerability settings, environmental forcing functions and changes of fishing pressure for simulating dynamics of marine populations. A mass-balance Ecopath model was saved for each simulated year, thus obtaining annual estimates of the input variables for calculating $\mathrm{L}$ and $\mathrm{p}_{\text {sust }}$ over time. Moreover, keeping all the environmental factors constant and changing the fishing pressure exerted by chosen fleets, 6 future scenarios were explored for the North Sea model (Christensen et al. 2002), thus obtaining insights into the sustainability of alternative management policies.

(3) Data sets with different degrees of aggregation of landings for various marine areas were used to estimate the $\mathrm{L}$ index and $\mathrm{p}_{\text {sust }}$. Aggregated data for main marine ecosystem types (open oceans, upwellings, tropical shelves, temperate shelves and coastal areas and reefs) were taken from Pauly \& Christensen (1995) for the years 1988 to 1991. Disaggregated landing statistics for the Mediterranean basin and the Black Sea enabled estimation of $\mathrm{TL}_{\mathrm{c}}$ and PPR by means of equations proposed by Pauly et al. (1998a) and Pauly \& Christensen (1995), respectively. Data included official landings, discards and illegal, unregulated or unreported catches (IUU). PP estimates were taken from published data and a characteristic TE for each ecosystem type was estimated from the set of 91 ecosystem models (Appendix 2).

Given a reference level of $p_{\text {sust }}=p$, the relative target value $L_{p}$ can be achieved with different strategies combining appropriate values of $\mathrm{TL}_{\mathrm{C}} \% \mathrm{PPR}, \mathrm{TE}$ and $\mathrm{P}_{1}$. Assuming a constant fishing strategy fishery (i.e. $\mathrm{TL}_{\mathrm{C}}$ constant) and ecosystem functioning (i.e. TE and $\mathrm{P}_{1}$ constant), target $\% \mathrm{PPR}_{\mathrm{p}}$ can be estimated by inverting Eq. (6). On the basis of target and actual $\mathrm{PPR}\left(\% \mathrm{PPR}_{\mathrm{p}}, \% \mathrm{PPR}^{0}\right.$ respectively) along with actual catches $\left(\mathrm{Y}^{0}\right)$, the corresponding ecosystem-based maximum sustainable catches $\left(\mathrm{EMSC}_{\mathrm{p}}\right.$ ) (Tudela et al. 2005) can be estimated as:

$$
\mathrm{EMSC}_{\mathrm{p}}=\frac{\% \mathrm{PPR}_{\mathrm{p}}}{\% \mathrm{PPR}^{0}} \cdot \mathrm{Y}^{0}=\frac{\left(-\mathrm{L}_{\mathrm{p}} \cdot \ln \mathrm{TE} \cdot \mathrm{TE}^{1-\mathrm{TL}_{\mathrm{C}}}\right)}{\% \mathrm{PPR}^{0}} \cdot \mathrm{Y}^{0}
$$

$\mathrm{EMSC}_{\mathrm{p}}$ represents the maximum catch that allows the ecosystem to achieve a given reference level of $\mathrm{p}_{\text {sust }}=$ p. Therefore $\mathrm{EMSC}_{75}$ and $\mathrm{EMSC}_{95}$ for the 2 reference values chosen $\left(p_{\text {sust }}=75 \%, 95 \%\right)$ represent a practical, though approximate, guide for fishery management. 


\section{RESULTS}

\section{Ecosystem-based reference framework for fisheries management}

Fig. 2 shows the $3 \mathrm{D}$ plot of $\% \mathrm{PPR}_{\mathrm{a}}, \mathrm{TL}_{\mathrm{c}}$ and $\mathrm{TE}$ values for the 51 classified models and surfaces that represent points with equal loss in secondary production, i.e. with equal probabilities of the ecosystem being sustainably fished ( $\mathrm{p}_{\text {sust }}=0$ and $100 \%$ ).

Reference values and confidence intervals for the L index are estimated applying Eq. (7) and the jackknife method to the well-studied and classified models (Table 1) obtaining $\mathrm{L}_{50 \%}=0.054 \pm 0.014, \mathrm{~L}_{75 \%}=0.021 \pm$ 0.013 and $\mathrm{L}_{95 \%}=0.007 \pm 0.007$ using $\% \mathrm{PPR}_{\mathrm{a}}$ and $\mathrm{L}_{50 \%}$ $=0.050 \pm 0.010, \mathrm{~L}_{75} \%=0.019 \pm 0.014$ and $\mathrm{L}_{95} \%=0.009 \pm$ 0.008 using $\% \mathrm{PPR}_{\mathrm{b}}$. Fig. 3 reports the relationship between $L$ and $p_{\text {sust }}$ found using $P P R_{a}$.

Comparison between the exploitation status based on detailed information available (column 3, EO, Table 1) with the exploitation status estimated on the basis of the $\mathrm{L}$ index (Columns $7, \mathrm{EO}_{\mathrm{a}}$ and 10, $\mathrm{EO}_{\mathrm{b}}$, Table 1) provides a basis for inferring the usefulness of this novel index in quantifying ecosystem overfishing. This comparison results in a different status with respect to the preliminary classification for a few models mainly represented by reconstruction of past eco- systems (Eastern Bering Sea 1950s, Newfoundland 1900 and Northern British Columbia 1900) and upwelling areas (North Benguela 1978 to 1983, Peru 1973 to 1981). Other ecosystems show correct classification within the confidence interval: the North Sea (1981), the Northern British Columbia (1950 and 2000), the Bay of Bengal (1984 to 1986) and the Gulf of Thailand (1980s). However, $80 \%$ of the models are correctly classified in this calibrating procedure.

\section{Assessment of ecosystem exploitation levels}

The calculation of the $\mathrm{L}$ index and estimation of $\mathrm{p}_{\text {sust }}$ values for the 40 unclassified ecosystem models (Table 2) produces a quantification of the sustainability of fisheries that is consistent with the partial information available for more than $75 \%$ of the cases. Clear exceptions are the West Greenland model of the shrimp trawling areas (1994) for temperate areas, the continental shelf of southern Brazil (1990s), the Gulf of Thailand (1993) and Kuala Trengganu (1980s) among tropical areas, Celestun lagoon among lagoons, and California (1965 to 1972) among upwellings. Among the 40 represented ecosystems, 16 are assessed as overfished and 24 as sustainably exploited.

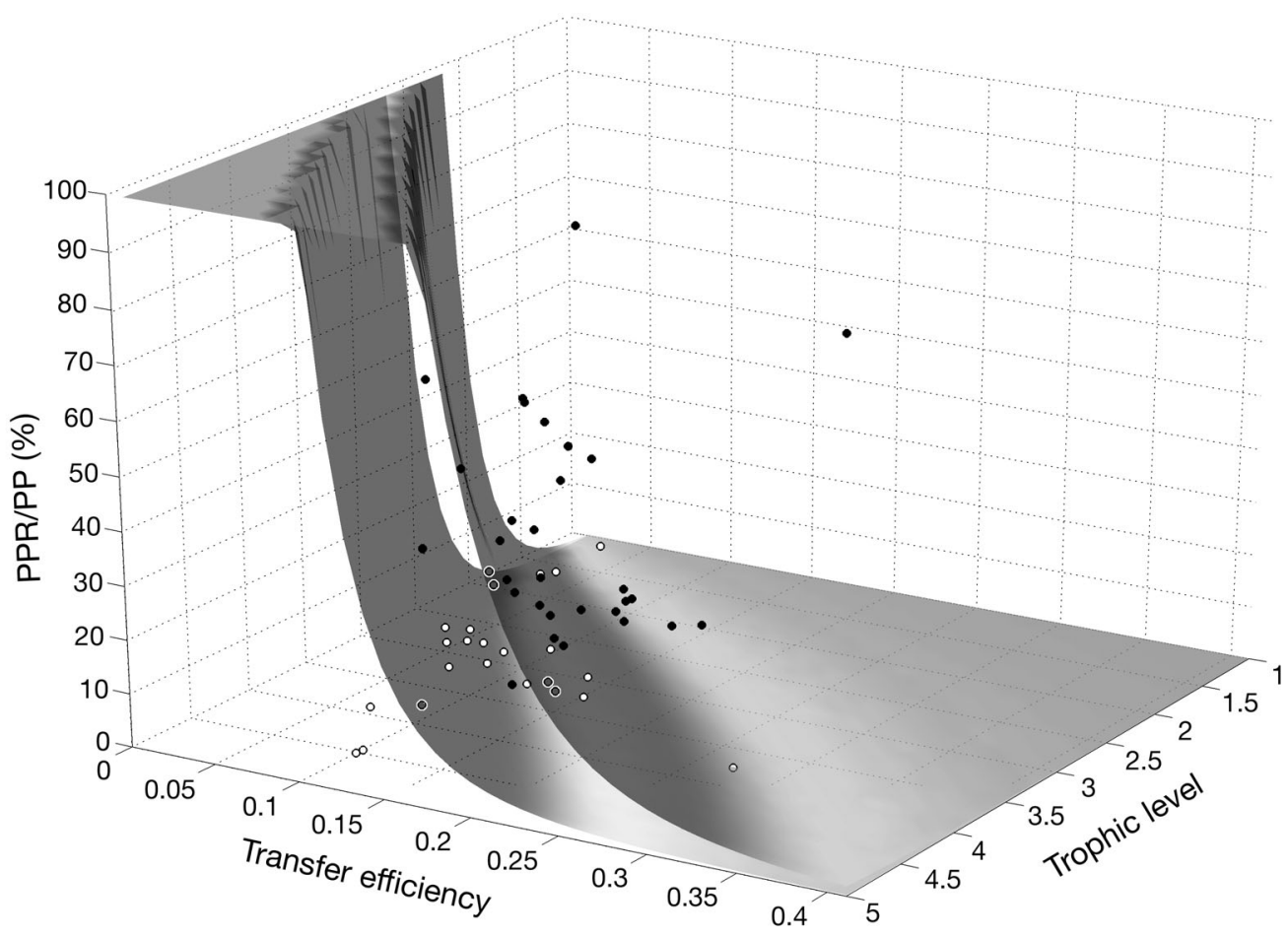

Fig. 2. Percent of primary production required to sustain the fishery $\left(\% P P R_{a}\right)$, trophic level of the catches and transfer efficiency data for the ecosystem models classified as sustainably fished (open circles, shaded when below surfaces) and overfished (black circles). Reference surfaces, $\mathrm{L}_{0 \%}$ (left) and $\mathrm{L}_{100 \%}$ (right) are also represented. The space above the right hand curve includes all points of surely overfished ecosystems, while the space below the left hand curve defines sustainably fished ecosystems with a $100 \%$ probability 


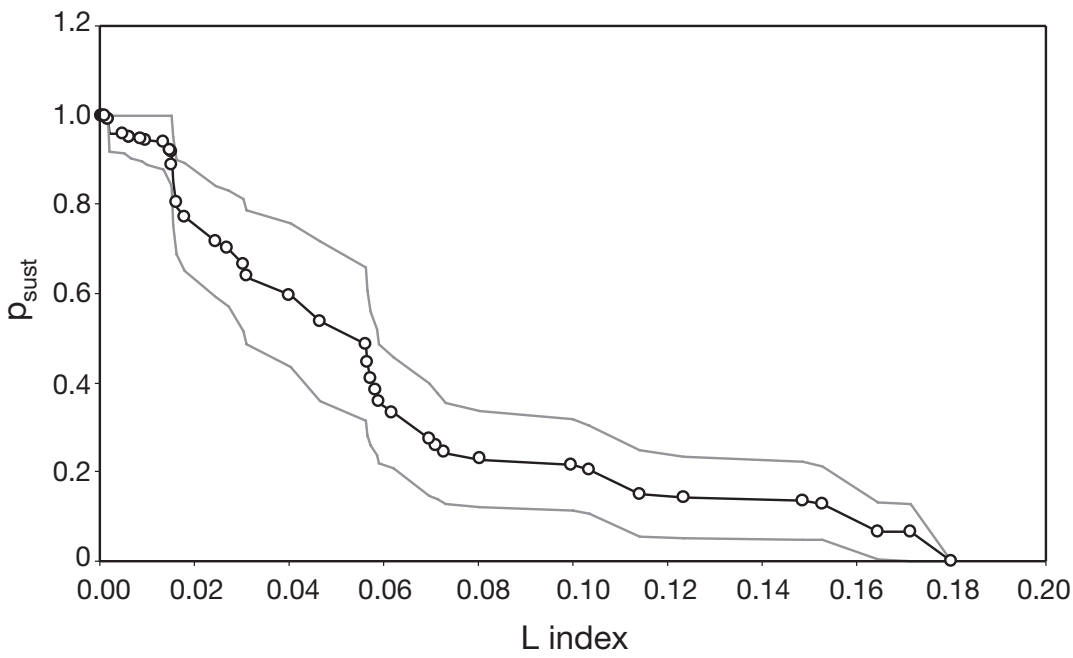

Fig. 3. Values indicating the probability of an ecosystem being sustainably fished ( $\left.p_{\text {sust }}\right)$ vs. L index obtained by application of the index to classified models. Nominal values refer to the 51 classified models (O), while averages $(-)$ and confidence intervals $(-)$ are obtained by applying the resampling method. This plot, referring to $\mathrm{PPR}_{\mathrm{a}}$ (percentage of primary production required to sustain the fishery from primary producers only), can be used for assessing the current level of exploitation for an ecosystem, once provided with an estimate of the L index, and for estimating ecosystem-based maximum sustainable catches (EMSC) once a $\mathrm{p}_{\text {sust }}$ value is fixed as reference limit
Fig. 4 reports L values over time estimated by using the 4 dynamic ecosystem models. South Benguela is sustainably fished throughout all the years analysed. Eastern Tropical Pacific is in a sustainable framework but $\mathrm{L}$ has a positive trend, indicating a decrease in sustainability. The North Sea is overexploited throughout the whole time series, indicating that the fisheries are non-sustainable. However, the negative trend in $\mathrm{L}$ indicates that this ecosystem may be moving towards relatively more sustainable fishing levels. West Coast Vancouver Island shows high variability in the $\mathrm{L}$ index and a prevalence of periods of overexploitation. However, sustainability increased over the last $10 \mathrm{yr}$ ( $\mathrm{p}_{\text {sust }}$ increases).

All the alternative scenarios simulated for the North Sea (Fig. 5) show an increase in the sustainability of fishing activities at the ecosystem level. Scenario 6 (which implied a $20 \%$ reduction on all
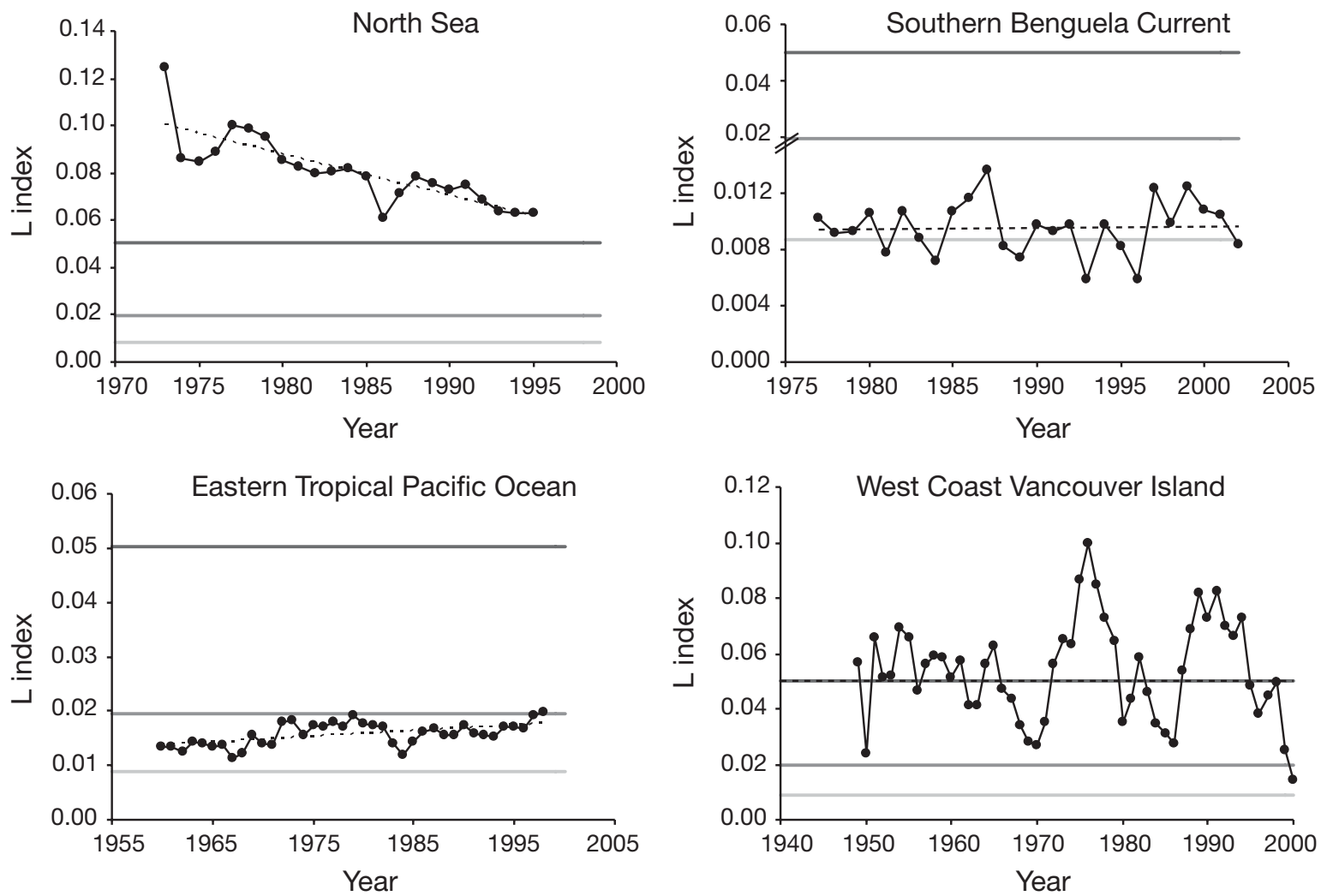

Fig. 4. Estimation of the L index of ecosystem overfishing over time for 4 ecosystem models. The index data (•) are estimated on the

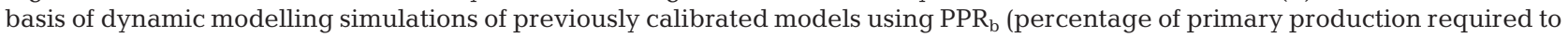
sustain the fishery, including the detritus-based food web). Analysis done for PPR (see Fig.3) gave analogous results. Dotted line: L index trend; along with the reference levels for the L values: $\mathrm{L}_{50 \%}$ (dark grey), $\mathrm{L}_{75} \%$ (medium grey) and $\mathrm{L}_{95} \%$ (light grey) 


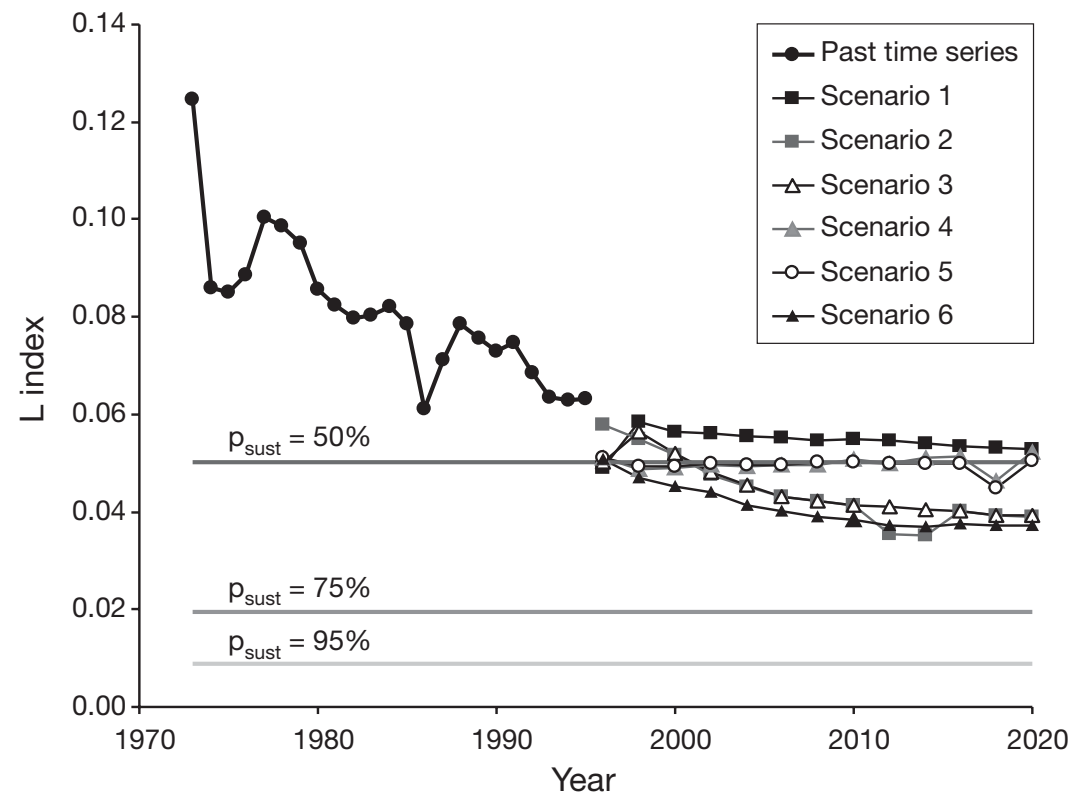

Fig. 5. L index estimated over time using $\mathrm{PPR}_{\mathrm{b}}$ from a dynamic model of the North Sea ecosystem using past fishing pressure (1973-1995) and under 6 alternative future scenarios of fishing (1996-2020). Scenarios represent: (1) no fishing on juvenile groups from 1999; (2) no fishing on small pelagic fishes from 1999; (3) no fishing on juvenile groups or small pelagic fishes from 1999; (4) $20 \%$ reduction on all fished groups from 1999; (5) $20 \%$ reduction on all fished groups, no fishing on juveniles from 1999; and (6) $20 \%$ reduction on all fished groups,

no fishing on small pelagic fishes from 1999; $\mathrm{P}_{\text {sust }}$ defined in Fig. 3 legend fished groups and no fishing on small pelagic fish) shows the best results in terms of sustainability of the fishery.

Values of the $\mathrm{L}$ index and $\mathrm{p}_{\text {sust }}$ by ecosystem type (Table 3) indicate high sustainability levels for open oceans $\left(p_{\text {sust }}=100 \%\right)$, low sustainability for upwelling and tropical shelves ( $p_{\text {sust }}=35.36$ and $33.19 \%$, respectively) and particularly low sustainability for coastal areas $(21.57 \%)$. Intermediate exploitation levels are estimated for temperate shelves $(53.78 \%)$ and for global data $(53.77 \%)$. Application of the L index to the Mediterranean and Black seas highlights intermediate sustainability levels (53.77 and $53.78 \%$, respectively) when considering the systems as a whole. Sustainability levels departing from the intermediate values are found in subsystems such as the Northern and Central Adriatic Sea (77.05\%) and the Southern Catalan Sea (35.34\%) (see Table 1). Using $\mathrm{PPR}_{\mathrm{b}}$, sustainability of fishery decreases dramatically both in the Catalan and the Adriatic Seas (28.60 and $37.90 \%$, respectively).

Table 3. Estimated probabilities of the ecosystem to be sustainably fished ( $\mathrm{p}_{\text {sust }}$ ) and ecosystem-based maximum sustainable catches (EMSC) by ecosystem type and for Mediterranean regional data with \%PPR $($ see Fig. 3 legend). Transfer efficiency (TE) estimated from average ecosystem types values (see Appendix 2, Table A2) if not otherwise indicated; input data ( $\mathrm{PP}, \mathrm{TL}_{\mathrm{c}}$, catches and discards) from Pauly \& Christensen (1995) for 1988-1991 if not otherwise indicated; catches modified to consider discards and illegal, unregulated or unreported catches (IUU); change ${ }_{75}$ and change ${ }_{95}$ indicate percentage reduction of catches needed from actual value to EMSC $_{75}$ and EMSC $_{95}$, respectively

\begin{tabular}{|c|c|c|c|c|c|c|c|c|c|c|}
\hline & $\begin{array}{l}\mathrm{TE} \\
(\%)\end{array}$ & $\begin{array}{c}\mathrm{PP} \\
\left(\mathrm{gC} \mathrm{m}^{-2} \mathrm{yr}^{-1}\right)\end{array}$ & ${ }^{T L_{c}}$ & $\begin{array}{l}\text { Catches } \\
\text { and discards } \\
\left(\mathrm{t} \mathrm{km}^{-2} \mathrm{yr}^{-1}\right)\end{array}$ & $\begin{array}{l}\text { PPR } \\
(\%)\end{array}$ & $\begin{array}{l}p_{\text {sust }} \\
(\%)\end{array}$ & $\begin{array}{c}\mathrm{EMSC}_{75} \\
\pm \mathrm{SD} \\
\left(\mathrm{t} \mathrm{km}{ }^{-2} \mathrm{yr}^{-1}\right)\end{array}$ & $\begin{array}{c}\text { Change }_{75} \\
(\%)\end{array}$ & $\begin{array}{c}\mathrm{EMSC}_{95} \\
\pm \mathrm{SD}^{-1} \\
\left(\mathrm{t} \mathrm{km}{ }^{-2} \mathrm{yr}^{-1}\right)\end{array}$ & $\begin{array}{c}\text { Change }_{95} \\
(\%)\end{array}$ \\
\hline \multicolumn{11}{|l|}{ Ecosystem type } \\
\hline Open oceans & 12 & 103 & 4.0 & 0.012 & 1.75 & 100.00 & $0.171 \pm 0.11$ & - & $0.062 \pm 0.057$ & - \\
\hline Upwellings & 5 & 973 & 2.8 & 25.560 & 39.31 & 35.36 & $8.699 \pm 5.606$ & -66 & $3.133 \pm 2.918$ & -88 \\
\hline Tropical shelves & 10 & 310 & 3.3 & 2.871 & 28.95 & 33.19 & $0.926 \pm 0.597$ & -68 & $0.334 \pm 0.311$ & -88 \\
\hline Temperate shelves & 14 & 310 & 3.5 & 2.306 & 12.92 & 53.78 & $0.973 \pm 0.627$ & -58 & $0.35 \pm 0.326$ & -85 \\
\hline Coastal areas and reefs & 13 & 890 & 2.5 & 10.510 & 4.40 & 21.57 & $2.113 \pm 1.362$ & -80 & $0.761 \pm 0.709$ & -93 \\
\hline Global data (1988-1991) & 12 & 126 & 2.8 & 0.260 & 4.71 & 53.77 & $0.108 \pm 0.07$ & -58 & $0.039 \pm 0.036$ & -85 \\
\hline \multicolumn{11}{|c|}{ Mediterranean data } \\
\hline $\begin{array}{l}\text { Mediterranean Sea } \\
\text { (2001) }\end{array}$ & 12 & $142^{\mathrm{c}}$ & $3.08^{\mathrm{e}}$ & $0.637^{\mathrm{e}}$ & 8.60 & 53.77 & $0.263 \pm 0.169$ & -59 & $0.095 \pm 0.088$ & -73 \\
\hline Black Sea (2001) & 12 & $322^{\mathrm{e}}$ & $3.04^{\mathrm{e}}$ & $1.644^{\mathrm{e}}$ & 7.50 & 53.78 & $0.714 \pm 0.46$ & -57 & $0.257 \pm 0.24$ & -72 \\
\hline $\begin{array}{l}\text { South Catalan Sea } \\
(1994-2000)\end{array}$ & $13^{\mathrm{a}}$ & $157^{\mathrm{d}}$ & $3.12^{\mathrm{a}}$ & $5.356^{\mathrm{a}}$ & $9.45-10.6$ & $35.34-33.15$ & $1.777 \pm 1.145$ & -67 & $0.64 \pm 0.596$ & -79 \\
\hline $\begin{array}{l}\text { Northern \& Central } \\
\text { Adriatic Sea (1990s) }\end{array}$ & $10^{\mathrm{b}}$ & $115^{\mathrm{b}}$ & $3.07^{\mathrm{b}}$ & $2.445^{\mathrm{b}}$ & $6.59-15.0$ & $77.05-53.74$ & $2.04 \pm 1.315$ & -17 & $0.735 \pm 0.684$ & -46 \\
\hline \multicolumn{11}{|l|}{${ }^{\mathrm{a} C}$ Coll et al. (2006) } \\
\hline \multicolumn{11}{|l|}{${ }^{b}$ Coll et al. (2007) } \\
\hline \multicolumn{11}{|l|}{${ }^{\mathrm{C} B o s c}$ et al. (2004) } \\
\hline \multicolumn{11}{|l|}{${ }^{\mathrm{d} E \text { Estrada (1996) }}$} \\
\hline${ }^{\mathrm{e} S e a}$ Around Us (2007) & & & & & & & & & & \\
\hline
\end{tabular}


Estimated EMSC $_{75 \%}$ (Table 3) is substantially lower than current catches for upwelling regions $(-66 \%)$, tropical shelves $(-68 \%)$, temperate shelves $(-58 \%)$ and coastal areas $(-80 \%)$. Adopting a reference of $\mathrm{p}_{\text {sust }}$ $=95 \%$, the difference with current catches is about 85 to $90 \%$ for all ecosystem types. In order to reach sustainability levels of $\mathrm{p}_{\text {sust }}=75$ and $95 \%$, catches at a global scale need to be decreased by 58 and $85 \%$, respectively.

A reference probability of $\mathrm{p}_{\text {sust }}=75 \%$ is achieved through reduction of catches by $59 \%$ for the whole Mediterranean basin, by $57 \%$ for the Black Sea and by 67 and $17 \%$ for the South Catalan and Adriatic Seas, respectively. Reduction of catches by 73, 72, 79 and $46 \%$, respectively, are needed to reach the reference probability of $95 \%$, i.e. $\mathrm{EMSC}_{95 \%}$.

\section{DISCUSSION}

Loss in secondary production takes into account both features of exploitation activities $\left(\mathrm{TL}_{\mathrm{c}}\right.$ and $\left.\mathrm{PPR}\right)$ and ecosystem properties (PP and TE) and provides an ecological basis for defining the $\mathrm{L}$ index, an original composite measure of the ecosystem effects of fishing. Loss in production has emerged from a comprehensive integration of recent ecological principles and ideas applied for evaluating fishery impacts (Pauly \& Christensen 1995, Pauly et al. 1998a) and represents a further step of ideas proposed in Tudela et al. (2005). The inclusion of TE accounts for differences in ecosystem functioning, thus allowing for the consistent application of the $\mathrm{L}$ index to different ecosystem types for a broad assessment of ecosystem effects of fisheries.

\section{Performance of the $L$ index}

Loss in secondary production estimated for the set of previously classified models highlights the ability of the L index to characterize systems as overexploited or sustainably fished. The high classification success of previously classified ecosystems (80\%, Table 1) and the high consistency of classification with respect to the fragmentary information available for other ecosystem models (Table 2) validate our initial assumption that the relative loss in secondary production can be a proxy for the impact of fishing on the ecosystem.

Inconsistencies emerging in the calibration process regard mainly past ecosystem models (eastern Bering Sea [1950s], Newfoundland [1900] and northern British Columbia [1900]) that are considered sustainably exploited on the basis of available information, but that our assessment evaluates as overexploited (Table 1).
Such disagreement can be explained by the high degree of uncertainty embedded in the reconstruction of historical ecosystems (Heymans 2003) and by the fishing pressure on marine mammals, which was higher in the past (Tudela et al. 2005). The L index application assesses the Newfoundland ecosystem as sustainably fished from 1985 to 1987 ( $p_{\text {sust }}=88.96$ to $78.61 \%)$, in contrast with available information (Table 1) but in agreement with biomass estimates for Gadus morhua (Atlantic cod) and Pandalus borealis (northern shrimp) obtained from research surveys and CPUE data (Worm \& Myers 2003). The relatively high biomass of cod at the end of the 1980s allowed fishing operations to maintain a high fishing pressure on this species. However, Northern cod collapsed in the early 1990s, followed by a regime shift (Steele 1998) with an increase in northern shrimp. This brought the ecosystem to a highly overfished situation in the $1990 \mathrm{~s}\left(\mathrm{p}_{\text {sust }}=\right.$ 13.6 to $12.8 \%$ ), resulting in the closure of the fishery in 1992 (Hilborn et al. 2003).

Some of the inconsistently classified models have $\mathrm{p}_{\text {sust }}$ close to $50 \%$ or within the confidence interval. Thus, their misclassification has low reliability. Strong disagreement between our assessment and previous evaluations (see Hilborn et al. 2003, Worm \& Myers 2003, Myers \& Worm 2005) consist of a few cases such as the West Greenland trawling area, the Faroe Islands seas, the Adriatic Sea and upwelling areas. The West Greenland shrimp trawling area (Model 65), Faroe Islands seas (Model 59) and upwellings (Models 86 to 91) are ecosystems where environmental factors (e.g. climate variability) could have produced negative effects (Pedersen et al. 2004) masking a sustainable exploitation as estimated by the index (Table 2). The Faroe Islands seas are assessed by the L index as exploited at very low levels of sustainability, while estimates of spawning stock biomass for cod suggested that they were not very depleted with respect to virgin biomass (Myers \& Worm 2005). However, climatic variability has a major impact on fish landings in the region (Jakupsstovu \& Reinert 1994).

In the case of the Adriatic Sea, the assessment is in contrast with information collected when using $\mathrm{PPR}_{\mathrm{a}}$ but not when considering $\mathrm{PPR}_{\mathrm{b}}$ (Table 1). Since a relevant fraction of energy for the food web comes from non-living organic matter in this ecosystem (Coll et al. 2007), this result highlights the importance of considering sources of energy other than primary production.

Despite these exceptions, the evaluation of the sustainability of fisheries through the L index is consistent with published analyses conducted using single species or community data. Very low sustainability of fisheries in the Gulf of Mexico (Models 28, 66, 73) agrees with low shark biomass assessed on the basis of pelagic longline logbooks (Baum \& Myers 2004; Tables 1 \& 2). 
Non-sustainability of fisheries in Newfoundland from 1995 to 2000, in the North Sea in 1981, in the Baltic Sea in 1974 (Models 11, 15, 53) and sustainability of fisheries for the eastern Scotian Shelf from 1980 to 1985, the Gulf of Saint Lawrence from 1985 to 1987 and Iceland in 1997 (Models 20, 22, 61) is consistent, for the respective periods, with evaluations based on the status of large predatory fishes (Myers \& Worm 2005) and on a meta-analysis of time series of cod and shrimp biomass (Worm \& Myers 2003; Tables 1 \& 2). Stable cod biomass over time for Iceland and the Norwegian Barents Sea (Worm \& Myers 2003) is in agreement with our findings (Models $61 \& 62$; Table 2). The increase of cod stock for Skagerrak-North Sea (Worm \& Myers 2003) — now rebuilding (Hilborn et al. 2003)-agrees with the increasing sustainability of fisheries found in our analysis for North Sea models representing different periods (Models 13, 14, 15; Table 1). Assessment of very low sustainability levels for northern British Columbia and the west coast of Vancouver Island (Models 18, 19, 64; Tables $1 \& 2$ ) is in accordance with the evidence of failure of fishery management based on single stock assessment (Hilborn et al. 2003). High variability estimated for cod and shrimp biomass in Gulf of Maine (Worm \& Myers 2003) might explain the result presented for this ecosystem (Model 60; Table 2).

When applied to mass balance model results, the $\mathrm{L}$ index only refers to the time period specified by the model. Thus, in the case of the eastern Scotian Shelf for example, the ecosystem is assessed as sustainable for 1980 to 1985 , when groundfish stocks were high. However, other assessments over a longer period of time indicate that by 1992, the Atlantic cod stock had collapsed and the ecosystem had fundamentally changed (Worm \& Myers 2003, Bundy et al. 2005). A second model for the eastern Scotian Shelf for 1995 to 2000 (Bundy 2005) again indicates a sustainable system. However, in this case, since the groundfish fishery was closed in 1993, fishing activity was refocused on invertebrate fisheries which are still healthy. By looking at 2 snapshots, the transition between the 2 states was missed. Thus, in order to follow trends in the L index, it should be applied to a continuous series of landings data or to a dynamic model.

\section{Regional and global quantification of ecosystem overfishing}

Application of the index to ecosystem dynamics obtained from EwE model simulations provides insights on the sustainability of fisheries over time. Our results from such an application agree with other evaluations based on field data. The Southern Benguela has been suggested to be moderately exploited (Shannon et al.
2004). Exploitation of the eastern tropical Pacific Ocean seems to be limited by physical and technological factors although sustainability of this open sea decreases over time due to excessive pressure on high trophic levels (Cox et al. 2002). West Coast Vancouver Island is subjected to high fishing pressure under high environmental variability, represented in the dynamic model through a forcing function on primary production (Martell 2002). Management of the North Sea ecosystem has been implemented, increasing the sustainability of exploitation (Hilborn et al. 2003).

However, simulations of different future scenarios of fishing activities in the North Sea (Christensen et al. 2002) show that a further increase in the sustainability of exploitation can be achieved only through a substantial reduction of catches and increase of $\mathrm{TL}_{\mathrm{c}}$, which is not necessarily obtained through increased fishing of higher TLs, but instead, by decreasing the proportion of low TL species in the catches (Fig. 5).

Application of the index to global landing data sets provides a basis for inferring that coastal areas, coral reefs and upwellings show very low probabilities of being sustainably fished, while temperate and tropical shelves show intermediate probabilities. High sustainability of the fisheries found for open oceans is consistent with the relatively low yields and high trophic levels of the catches taken from this environment. Open oceans are subjected to lower fishing pressure compared to coastal systems (Caddy et al. 1998) and they represent the upper reference for sustainably exploited systems in the presented analysis. However, as previously discussed, the eastern tropical Pacific Ocean shows a continuous increase with time in the L index, implying a decrease in sustainability, in accordance with the observed decline of top predators (Myers \& Worm 2003, 2005). Therefore, the assessment obtained for open oceans should be used cautiously, especially since only 2 oceanic ecosystems were included in the analysis. More robust estimates will depend on the future availability of more data.

The important risks of ecosystem overfishing found for upwelling, coastal and shelf areas are in accordance with the concentration of marine catches in these marine environments (Pauly \& Christensen 1995). These risks underline the need for a dramatic reduction of the catches.

Application of reference targets to areas for which detailed descriptions of fisheries are available (in terms of catches, discards and IUU, such as the Mediterranean Sea), confirms the need for a substantial decrease in yield and points to a serious risk of overfishing, which arises from intense current and historical fishing pressure and exploitation (Bas et al. 1985). At the global scale, a $58 \%$ reduction in catches would be needed in order to reach a $\mathrm{p}_{\text {sust }}=75 \%$. 


\section{Properties and limitations}

A suitable ecosystem-based indicator should be: (1) quantitative and sensitive to changes in the structure and functioning of ecosystems induced by fishing activities; (2) easy to calculate, in order to facilitate its application in data-poor cases; (3) low-cost to allow its application in developing countries; and (4) practical for defining reference values (Link 2002). Analyses, applications and results presented in this work provide evidence that the L index matches these requirements. In particular, estimated reference levels for sustainable exploitation provide quantitative, practical information (in terms of reduction of catches) for management. Moreover, although trophodynamic EwE models can provide a platform for evaluating alternative management solutions, the L index is not dependent on these models. Thus, its application can be generalized to different modelling approaches or to catch data, providing estimates of $\mathrm{PP}, \mathrm{TE}, \mathrm{TL}_{\mathrm{c}}$ are available.

The loss in production is theoretically derived as a deterministic function of $\% \mathrm{PPR}, \mathrm{TL}_{\mathrm{c}}$ and $\mathrm{TE}$. Thus, the $\mathrm{L}$ index integrates the properties of these indicators. It accounts for changes in nutrients and PP, the effects of which propagate upwards throughout the trophic web (Pace et al. 1999), and captures the negative effects expected when fishing down the food web (Pauly et al. 1998a).

The \%PPR and $\mathrm{TL}_{\mathrm{C}}$ can be estimated from catch statistics or from ecosystem models (Pauly \& Christensen 1995, Stergiou \& Karpouzi 2002), but not TE. This appears to be a weak point of the proposed index. However, using a wide set of ecosystem models, it was possible to estimate standard values of TE by ecosystem type (Appendix 2). Although an overall single value of TE for a given ecosystem is an approximation of the efficiencies of all processes, results of the sensitivity analysis show that improvements in the TE estimate only provide moderate improvement in estimates of loss in secondary production (Appendix 1).

However, the sensitivity analysis also showed that a $1 \%$ change in $\mathrm{TL}_{\mathrm{c}}$ produces approximately a $5.8 \%$ change in the L index. The high sensitivity of the $\mathrm{L}$ index to errors in $\mathrm{TL}_{\mathrm{c}}$ and the uncertainty that characterizes TL estimates (Pinnegar et al. 2002) may explain some of the observed inaccuracies of the index in evaluating the ecosystem exploitation status. The above implies that particular attention should be paid to calculating $\mathrm{TL}_{\mathrm{c}}$ as accurately as possible.

Some limitations in the use of the $\mathrm{L}$ index might be identified on the basis of assumptions and hypotheses pointed out in the theoretical derivation. The L index is identified at steady state. Therefore, it should not be applied to situations with very sharp changes in exploitation or primary production. Scaling PPR on actual $\mathrm{P}_{1}$ allows us to take into account variability in production, and dynamic simulations have been used to show that the index can correctly identify overexploited and sustainably fished years when modifying fishing intensity. This scaling reduces the $\mathrm{L}$ index to a relative measure and enables the application of the index to data expressed in any unit. The reference values developed here are for weight or carbon units only and should only be (cautiously) applied to systems using the same units.

The L index might not take into account the compensatory effects that arise when changing fishing pressure. Removal of part of the production by the fishery would leave more resources available to the remaining individuals, resulting in lower mortality rates, for example. Such an effect, although considered common (Walters \& Martell 2004), seems less important than the direct effect of the removal of production on the upper TLs (Walters et al. 2005), thus justifying our disregard of compensatory effects at the ecosystem scale. Moreover, the index does not account for the delayed effects such as those on upper TLs due to changes in primary production and on lower TLs due to changes in fishery structure. Compensatory and time delayed effects can be included in the estimation of the $\mathrm{L}$ index when a dynamic model is used.

The L index might not correctly describe the depletion due to the massive removal of keystone species that would produce disproportionate or magnified effects on the trophic web, as would be the case for top predators in oceanic ecosystems (Libralato et al. 2006). However, the identified relationship between biodiversity and production (Tilman et al. 1997, Worm \& Duffy 2003) implies that the L index indirectly takes into account the decrease of biological diversity and the risk of extinction (Murawski 2000).

\section{Directions for future research}

The ecologically broad meaning of the L index necessarily implies a broad range of management solutions to accomplish with reference levels (e.g. increase in $\mathrm{TL}_{\mathrm{C}}$, decrease in catches, decrease in discards). Therefore, although results highlight the usefulness of the L index for quantitative ecosystem-based fisheries management, traditional stock-by-stock evaluations (Hilborn et al. 2003, Worm \& Myers 2003) should continue to play an important role in fisheries management. Nevertheless, the comparison between results obtained by applying of the L index and analyses based on traditional fish stocks data presented in this study highlights the complementary nature of the 2 approaches, thus supporting their combined use for quantitative ecosystem-based fisheries management 
(Pauly et al. 2002). Future research should point toward the use of a set of indicators for evaluating the effects of fishing at different ecological hierarchical levels (population, community, ecosystem), thus coupling single stock assessments with broad ecosystembased evaluations (Link 2002, Bundy et al. 2005).

New assessments for well-studied ecosystems, easily done by estimating the $\mathrm{L}$ index using values of PPR, $\mathrm{P}_{1}$, $\mathrm{TL}_{\mathrm{C}}$ and TE, would provide more evidence of its accuracy in quantifying the ecosystem effects of fishing. However, the performance of the $\mathrm{L}$ index in evaluating these effects should be validated by applying it to data-rich areas where assessment based on commonly available data (e.g. catches) can be compared with that based on experimental surveys. This validation should necessarily account for spatial and temporal patterns of ecosystem properties and fishing pressures. Spatiotemporal resolution of datasets might represent a limit for validation.

The L index has the advantage of being calculated directly from landing statistics by applying empirical formulas for estimating \%PPR and $\mathrm{TL}_{\mathrm{c}}$ (Pauly \& Christensen 1995, Pauly et al. 1998a). However, PPR should preferably be estimated using diet composition (DC) of the landed fishes ( $i$ ) and TL of their prey $(j)$. The equation provided by Pauly \& Christensen (1995) can be reformulated as:

$$
\mathrm{PPR}=\frac{1}{9} \sum_{i}\left[\mathrm{y}_{i} \cdot \sum_{j} \mathrm{DC}_{i j} \cdot\left(\frac{1}{\mathrm{TE}}\right)^{\mathrm{TL}_{j}-1}\right]
$$

This formula, due to a wide variation in TL for landed species (i), yields more precise estimates of PPR. Similarly, the L index should be estimated using the formulation proposed in the left side of Eq. (6), while the simplification represented by the right side should be used for facilitating graphic representation and for assessments based on aggregate datasets.

The high sensitivity of the $L$ index to the $\mathrm{TL}_{\mathrm{c}}$ necessitates the use of techniques that provide accurate and reliable TL estimates for marine species (Pinnegar et al. 2002). In cases where the confidence interval of $\mathrm{TL}_{\mathrm{C}}$ is wide, i.e. when fisheries operate on a broad spectrum, accuracy of the fishing status and EMSC estimates should be considered carefully. In order to obtain an accurate and reliable estimation of the ecosystem overfishing status, the index should be estimated by including discards and IUU in the PPR estimates, as they frequently comprise an important proportion of the catch (Alverson et al. 1994, Pauly et al. 2002).

In general, methods for estimating $\mathrm{PPR}, \mathrm{TL}_{\mathrm{c}}$ and $\mathrm{TE}$ with low error imply the use of quantitative ecosystem modelling (Christensen \& Walters 2004), which allows the inclusion of a large body of information and the direct quantification of input parameters for the
L index, avoiding empirical formulae and standard values. Availability of more ecological models for highly studied ecosystems will allow improvement both in the definition of reference values of the $\mathrm{L}$ index and in the accuracy of results provided. However, dramatic consequences of environmental fluctuations, ecological unpredictability and the unavoidable uncertainty associated with data still imply a broad use of the precautionary approach.

\section{CONCLUSIONS}

Theoretical loss in secondary production is used as a proxy for quantifying ecosystem effects of fishing and is formulated in a new index of ecosystem overfishing: the $\mathrm{L}$ index. The approach proposed integrates and complements previous analyses (Pauly \& Christensen 1995, Pauly et al. 1998a, Myers \& Worm 2003, Tudela et al. 2005), allowing a broad and general application of the index using both landings data and ecosystem models. The L index allows the estimation of ecosystem-based maximum sustainable catches that, when compared with current catches, might give approximate but direct and practical information regarding the degree of intervention required. Results show that moderate \%PPR values are only compatible with fisheries harvesting the higher part of the food web. This raises serious concern in the sustainability of current fishing regimes that, after having depleted stocks of large predators (Pauly et al. 1998a), are mainly characterised by strategies based on low $\mathrm{TL}_{\mathrm{c}}$ and high \% PPR (Pauly et al. 2002). In the framework of sustainable exploitation of biological resources, the approach proposed here represents a first broad estimation of sustainable reference levels for an ecosystem-based management of fisheries and is compatible with other approaches focusing on lower hierarchic levels (e.g. community, species).

Acknowledgements. We thank all the authors that kindly supplied the information and their personal experience concerning ecosystem models. We wish to acknowledge V. Christensen and C.J. Walters (UBC, Canada) for providing the model database and for giving useful advice. We thank E. Morello (ISMAR - CNR, Italy), A. Pastore and R. Pastres (Università Ca' Foscari, Italy) and C. Solidoro (OGS, Italy) for comments and suggestions. We thank A. Bundy (DFO, Canada) and 2 anonymous reviewers for helpful comments and corrections.

\section{LITERATURE CITED}

Ainsworth C, Ferriss B, Leblond E, Guénette S (2001) The Bay of Biscay, France; 1998 and 1970 models. In: Guénette S, Christensen V, Pauly D (eds) Fisheries impacts on North Atlantic ecosystems: models and analyses. Fish Cent Res Rep 9(4):271-313 
Ainsworth C, Heymans JJ, Pitcher T, Vasconcellos M (2002) Ecosystem models of northern British Columbia for the time periods 2000, 1950, 1900 and 1750. Fish Cent Res Rep 10(4):1-41

Aliñó PM, McManus LT, McManus JW, Nañola C, Fortes MD, Trono GC, Jacinto GS (1993) Initial parameter estimations of a coral reef flat ecosystem in Boliano, Pangasinan, Northwestern Philippines. In: Christensen V, Pauly D (eds) Trophic models of aquatic ecosystems. ICLARM Conf Proc 26:252-267

Alverson DL, Freeberg SA, Murawski SA, Pope JG (1994) A global assessment of fisheries bycatch and discards. FAO Fish Tech Paper 339:1-235

Arreguín-Sánchez F, Seijo JC, Valero-Pacheco E (1993b) An application of Ecopath II to the north continental shelf of Yucatán, México. In: Christensen V, Pauly D (eds) Trophic models of aquatic ecosystems. ICLARM Conf Proc 26: 269-278

Arreguín-Sánchez F, Valero-Pacheco E, Chávez EA (1993a) A trophic box model of the coastal fish communities of the southwestern Gulf of Mexico. In: Christensen V, Pauly D (eds) Trophic models of aquatic ecosystems. ICLARM Conf Proc 26:197-205

Baird D, Ulanowicz RE (1989) Seasonal dynamics of the Chesapeake Bay ecosystem. Ecol Monogr 59:329-364

Bas C, Macpherson E, Sardà F (1985) Fishes and fishermen. The exploitable trophic levels. In: Margalef R (ed) Key environments: western Mediterranean. Pergamon Press, Oxford, p 296-316

Baum JK, Myers RA (2004) Shifting baselines and the decline of pelagic sharks in the Gulf of Mexico. Ecol Lett 7:135-145

Bosc E, Bricaud A, Antoine D (2004) Seasonal and interannual variability in algal biomass and primary production in the Mediterranean Sea, as derived from 4 years of SeaWiFS observations. Global Biogeochem Cycles 18:1-17

Brando VE, Ceccarelli R, Libralato S, Ravagnan G (2004) Assessment of environmental management effects in a shallow water basin using mass-balance models. Ecol Model 172:213-232

Browder JA (1993) A pilot model of the Gulf of Mexico continental shelf. In: Christensen V, Pauly D (eds) Trophic models of aquatic ecosystems. ICLARM Conf Proc 26:279-284

Buchary E (2001) Preliminary reconstruction of the Icelandic marine ecosystem in 1950. In: Guénette S, Christensen V, Pauly D (eds) Fisheries impacts on North Atlantic ecosystems: models and analyses. Fish Cent Res Rep 9(4): 198-206

Buchary E, Alder J, Nurhakim S, Wager T (2002) Strategies for capture fisheries in the Bali Strait, Indonesia. In: Pitcher T, Cochrane K (eds) The use of ecosystem models to investigate multispecies management strategies for capture fisheries. Fish Cent Res Rep 10(2):24-32

Bundy A (2005) Structure and function of the eastern Scotian shelf ecosystem before and after the groundfish collapse in the early 1990s. Can J Fish Aquat Sci 62(7): 1453-1473

Bundy A, Pauly D (2001) Selective harvesting by small-scale fisheries: ecosystem analysis of San Miguel Bay, Philippines. Fish Res 53: 263-281

Bundy A, Lilly GR, Shelton PA (2000) A mass-balance model for the Newfoundland-Labrador shelf. Can Tech Rep Fish Aquat Sci 2310:1-157

Bundy A, Fanning P, Zwanenburg KCT (2005) Balancing exploitation and conservation of the Eastern Scotian Shelf ecosystem: application of a 4D ecosystem exploitation index. ICES J Mar Sci 62:503-510

Caddy JF, Carocci F, Coppola S (1998) Have peak fishery production levels been passed in continental shelf areas?
Some perspectives arising from historical trends in production per shelf areas. J Northw Atl Fish Sci 23:191-219

Campos LW (2003) An ecosystem model of San Pedro bay, Central Philippines. In: Silvestre G, Garces L, Ahmed M, Stobutzki I and others (eds) Assessment and management of tropical coastal fisheries in developing Asian countries. ICLARM Conf Proc 26:227-248

Chávez EA, Garduño M, Arreguín-Sánchez F (1993) Trophic dynamic structure of Celestum Lagoon, Southern Gulf of Mexico. In: Christensen V, Pauly D (eds) Trophic models of aquatic ecosystems. ICLARM Conf Proc 26:186-192

Cheung WL, Watson R, Pitcher T (2002) Policy simulation of fisheries in the Hong Kong marine ecosystems. In: Pitcher $\mathrm{T}$, Cochrane $\mathrm{K}$ (eds) The use of ecosystem models to investigate multispecies management strategies for capture fisheries. Fish Cent Res Rep 10(2):46-54

Christensen V (1995) A model of trophic interactions in the North Sea in 1981, the year of the stomach. Dana 11:1-28

Christensen V (1998) Fishery-induced changes in a marine ecosystem: insight from models of the Gulf of Thailand. J Fish Biol 53:128-142

Christensen V, Pauly D (1992) Ecopath II. A software for balancing steady-state models and calculating network characteristics. Ecol Model 61:169-185

Christensen V, Walters CJ (2004) Ecopath with Ecosim: methods, capabilities and limitations. Ecol Model 172:109-139

Christensen V, Beyer JE, Gislason H, Vinter M (2002) A comparative analysis of the North Sea based on Ecopath with Ecosim and Multispecies Virtual Population Analysis. In: Christensen V, Reck G, Maclean JL (eds) Proc INCO-DC Conf, Placing Fisheries in their Ecosystem Context. Galápagos Islands, Ecuador, 4-8 December 2000. ACP-EU Fish Res Rep 12:1-39

Coll M, Palomera I, Tudela S, Sardà F (2006) Trophic flows, ecosystem structure and fishing impact in the South Catalan Sea, Northwestern Mediterranean. J Mar Sys 59:63-96

Coll M, Santojanni A, Arneri E, Palomera I, Tudela, S (2007) An ecosystem model of the Northern and Central Adriatic Sea: analysis of ecosystem structure and fishing impacts. J Mar Sys 67:119-154

Cox SP, Martell SJ, Walters CJ, Essington TE, Kitchell JF, Boggs C, Kaplan I (2002) Reconstructing ecosystem dynamics in the central Pacific Ocean, 1952-1998. I. Estimating population biomass and recruitment of tunas and billfishes. Can J Fish Aquat Sci 59:1724-1735

Crowley PH (1992) Resampling methods for computationintensive data analysis in ecology and evolution. Annu Rev Ecol Syst 23:405-447

Daan N, Christensen V, Cury PM (eds) (2005) Quantitative ecosystem indicators for fisheries management. ICES J Mar Sci 62 (3):1-614

De Paula e Silva R, Sousa MI, Caramelo AM (1993) The Maputo bay ecosystem (Mozambique). In: Christensen V, Pauly D (eds) Trophic models of aquatic ecosystems. ICLARM Conf Proc 26:214-223

Delos Reyes M, Martens R (1994) Geoecology of Laguna de Bay, Philippines. I. Techno-commercial impact on the trophic level structure of the Laguna de Bay aquatic ecosystem, 1968-1980. Ecol Model 75/76:497-509

Department of Justice Canada (1996) Oceans Act. An act respecting the oceans of Canada. C31. Available at http://laws.justice.gc.ca/en/ShowFullDoc/cs/O-2.4///en

Dommasnes A, Christensen V, Ellertsen B, Kvamme C and others (2001) An Ecopath model for the Norwegian Sea and Barents Sea. In: Guénette S, Christensen V, Pauly D (eds) Fisheries impacts on North Atlantic ecosystems: models and analyses. Fish Cent Res Rep 9(4):213-239 
Estrada M (1996) Primary production in the northwestern Mediterranean. Sci Mar 60:55-64

European Community (2002) Council regulation no. 2371/2002 on the conservation and sustainable exploitation of fisheries resources under the Common Fishery Policy. Official Journal of the European Communities L358:59-79

FAO/FISHCODE (Food and Agriculture Organization of the United Nations/Norway Programme of assistance to developing countries for the implementation of the Code of Conduct for Responsible Fisheries) (2001) Report of a bio-economic modelling workshop and a policy dialogue meeting on the Thai demersal fisheries in the Gulf of Thailand, Hua Hin, Thailand, 31 May-9 June 2000. Rome, FAO, Field Report F-16

Fisheries Centre (2007) EwE database. Available at: www. ecopath.org

Guénette S, Morato T (2001) The Azores archipelago in 1997. In: Guénette S, Christensen V, Pauly D (eds) Fisheries impacts on North Atlantic ecosystems: models and analyses. Fish Cent Res Rep 9(4):271-313

Harvey CJ, Cox SP, Essington TE, Hansson S, Kitchell JF (2003) An ecosystem model of food web and fisheries interactions in the Baltic Sea. ICES J Mar Sci 60:939-950

Heymans JJ (2001) The Gulf of Maine, 1977-1986. In: Guénette S, Christensen V, Pauly D (eds) Fisheries impacts on North Atlantic ecosystems: models and analyses. Fish Cent Res Rep 9(4):129-149

Heymans JJ (2003) Ecosystem models of Newfoundland and Southeastern Labrador: additional information and analyses for 'Back to the Future'. Fish Cent Res Rep 11(5):1-81

Heymans JJ, Shannon LJ, Jarre-Teichmann A (2003) Changes in the northern Benguela ecosystem over three decades: 1970s, 1980s and 1990s. Ecol Model 172:175-195

Hilborn R, Branch TA, Ernst B, Magnusson A, Minte-Vera C, Schuerell MD, Valero JL (2003) State of the world fisheries. Annu Rev Environ Resour 28:359-399

Jackson JBC, Kirby MX, Berger WH, Bjorndal KA and others (2001) Historical overfishing and the recent collapse of coastal ecosystems. Science 293:629-638

Jakupsstovu SH, Reinert J (1994) Fluctuations in the Faroe Plateau stock. In: Jakobsson J, Astthorsson OS, Beverton $\mathrm{RJH}$, Bjoernsson B and others (eds) Cod and climate change. Proc Symp, Reykjavik, 23-27 August 1993. ICES Mar Sci Symp 198:194-211

Jarre-Teichmann A, Muck P, Pauly D (1991) Two approaches for modelling fish stock interactions in the Peruvian upwelling ecosystem. ICES Mar Sci Symp 193:178-184

Jarre-Teichmann A (1998) The potential role of mass balance models for the management of upwelling ecosystems. Ecol Appl 8(1) Supplement:93-103

Jennings S, Kaiser MJ (1998) The effects of fishing on marine ecosystems. Adv Mar Biol 34:201-351.

Lalli CM, Parsons TR (1993) Biological oceanography: an introduction. Pergamon Press, Oxford

Larkin PA (1996) Concepts and issues in marine ecosystem management. Rev Fish Biol Fish 6:139-164

Libralato S, Christensen V, Pauly D (2006) A method for identifying keystone species in food web models. Ecol Model 195:153-171

Lin H, Shao K, Kuo SR, Hsieh HL and others (1999) A trophic model of a sandy barrier lagoon at Chiku in Southwestern Taiwan. Estuar Coast Shelf Sci 48(5):575-588

Lindeman RL (1942) The trophic-dynamic aspect of ecology. Ecology 23:399-418

Link JS (2002) Ecological considerations in fisheries management: When does it matter? Fisheries 27:10-17

Lotze HK, Lenihan HS, Bourque BJ, Bradbury RH and others
(2006) Depletion, degradation and recovery potential of estuaries and coastal seas. Science 312:1806-1809

Mackinson S (2001) Representing trophic interactions in the North Sea in the 1880s, using the Ecopath mass-balance approach. In: Guénette S, Christensen V, Pauly D (eds) Fisheries impacts on North Atlantic ecosystems: models and analyses. Fish Cent Res Rep 9(4):35-98

Martell SJD (2002) Variation in pink shrimp populations off the west coast of Vancouver Island: oceanographic and trophic influences. PhD thesis, University of British Columbia, Vancouver

Mendoza JJ (1993) A preliminary biomass budget for the northeastern Venezuela shelf ecosystem. In: Christensen V, Pauly D (eds) Trophic models of aquatic ecosystems. ICLARM Conf Proc 26:285-297

Mendy AN, Buchary E (2001) Constructing the Icelandic marine ecosystem model from 1997 using a mass balance modelling approach. In: Guénette S, Christensen V, Pauly D (eds) Fisheries impacts on North Atlantic ecosystems: models and analyses. Fish Cent Res Rep 9(4):182-197

Mohammed E (2001) A model of the Lancaster Sound Region in the 1980s. In: Guénette S, Christensen V, Pauly D (eds) Fisheries impacts on North Atlantic ecosystems: models and analyses. Fish Cent Res Rep 9(4):99-110

Morissette L, Despatie SP, Savenkoff C, Hammill MO, Bourdages H, Chabot D (2003) Data gathering and input parameters to construct ecosystem models for the northern Gulf of St. Lawrence (mid-1980s). Can Tech Rep Fish Aquat Sci 2497:1-100

Murawski SA (2000) Definitions of overfishing from an ecosystem perspective. ICES J Mar Sci 57:649-658

Mustafa MG (2003) A trophic model of the coastal fisheries ecosystem of the Bay of Bengal, Bangladesh. In: Silvestre G, Garces L, Ahmed M, Stobutzki I and others (eds) Assessment and management of tropical coastal fisheries in developing Asian countries. ICLARM Conf Proc 26: 263-280

Myers RA, Worm B (2003) Rapid worldwide depletion of predatory fish communities. Nature 423:280-283

Myers RA, Worm B (2005) Extinction, survival or recovery of large predatory fishes. Phil Trans R Soc B 360:13-20

Nurhakim S (2003) Fishery resource of the north coast of central Java: an initial ecosystem analysis. In: Silvestre G, Garces L, Ahmed M, Stobutzki I and others (eds) Assessment and management of tropical coastal fisheries in developing Asian countries. ICLARM Conf Proc 26: 299-312

Okey TA, Pauly D (1998) A trophic mass-balance model of Alaska's Prince William Sound ecosystem, for the post-spill period 1994-1996, 2nd edn. Fish Cent Res Rep 7(4):1-146

Okey TA, Banks S, Born AF, Bustamante RH and others (2004) A trophic model of a Galápagos subtidal rocky reef for evaluating fisheries and conservation strategies. Ecol Model 172:383-401

Olson R, Watters G (2003) A model of the pelagic ecosystem in the eastern tropical Pacific Ocean. Bull Inter-Am Trop Tuna Comm 22(3):1-91

Pace ML, Cole JJ, Carpenter SR, Kitchell JF (1999) Trophic cascades revealed in diverse ecosystems. Trends Ecol Evol 14:483-488

Palomares ML, Reyes-Marchant P, Lair N, Zainure M, Barnabe G, Lasserre G (1993) A trophic model of a Mediterranean lagoon, Etang de Thau, France. In: Christensen V, Pauly D (eds) Trophic models of aquatic ecosystems. ICLARM Conf Proc 26:224-229

Pauly D, Christensen V (1993) Stratified models of large marine ecosystems: a general approach and an application to the 
South China Sea. In: Sherman K, Alexander LM, Gold BD (eds) Stress, mitigation and sustainability of large marine ecosystems. AAAS Press, Washington, DC, p 148-174

Pauly D, Christensen V (1995) Primary production required to sustain global fisheries. Nature 374:255-257

Pauly D, Christensen V, Dalsgaard J, Froese R, Torres F Jr (1998a) Fishing down marine food webs. Science 279: 860-863

Pauly D, Pitcher T, Preikshot D (1998b) Back to the future: reconstructing the Strait of Georgia ecosystem. Fish Cent Res Rep 6(5):1-99

Pauly D, Christensen V, Guenette S, Pitcher TJ and others (2002) Towards sustainability in world fisheries. Nature 418:689-695

Pedersen SA, Zeller D (2001) A mass balance model for the West Greenland marine ecosystem. In: Guénette S, Christensen V, Pauly D (eds) Fisheries impacts on North Atlantic ecosystems: models and analyses. Fish Cent Res Rep 9(4):111-127

Pedersen SA, Madsen J, Dyhr-Nielsen M (2004) Global international waters assessment. Arctic Greenland, East Greenland shelf, West Greenland shelf, GIWA regional assessment 1b, 15, 16, University of Kalmar/United Nations Environment Programme, Kalmar, Sweden

Pinnegar JK (2000) Planktivorous fishes: links between the Mediterranean littoral and pelagic. $\mathrm{PhD}$ thesis, University of Newcastle-upon-Tyne

Pinnegar JK, Jennings S, O'Brien CM, Polunin NVC (2002) Long-term changes in the trophic level of the Celtic Sea fish community and fish market price distribution. J Appl Ecol 39:377-390

Pranovi F, Libralato S, Raicevich S, Granzotto A, Pastres R, Giovanardi O (2003) Mechanical clam dredging in Venice lagoon: ecosystem effects evaluated with trophic massbalance model. Mar Biol 143:393-403

Rochet MJ, Trenkel VM (2003) Which community indicators can measure the impact of fishing? A review and proposals. Can J Fish Aquat Sci 60:86-99

Sánchez F, Olaso I (2004) Effects of fisheries on the Cantabrian Sea shelf ecosystem. Ecol Model 172:151-174

Saltelli A, Chan K, Scott EM (2000a) Sensitivity analysis. Wiley, Chichester

Saltelli A, Tarantola S, Campolongo F (2000b) Sensitivity analysis as an ingredient of modeling. Statist Sci 15: 377-395

Sea Around Us (2007) A global database on marine fisheries and ecosystems. Fisheries Centre, University British Columbia, Vancouver. Available at: www.seaaroundus.org

Shannon LJ, Christensen V, Walters CJ (2004) Modelling stock dynamics in the Southern Benguela ecosystem for the period 1978-2002. Afri J Mar Sci 26:179-196

Silvestre G, Selvanathan S, Salleh ANH (1993) Preliminary trophic model of the coastal fishery resources of Brunei Darussalam, South China Sea. In: Christensen V, Pauly D (eds) Trophic models of Aquatic ecosystems. ICLARM Conf Proc 26:300-306

Springer AM, Estes JA, van Vliet GB, Williams TM and others (2003) Sequential megafaunal collapse in the North Pacific Ocean: an ongoing legacy of industrial whaling? Proc Natl Acad Sci USA 100:12223-12228

Stanford R, Lunn K, Guénette S (2001) A preliminary model of the Atlantic coast of Morocco for the mid-1980s. In: Guénette S, Christensen V, Pauly D (eds) Fisheries impacts on North Atlantic ecosystems: models and analyses. Fish
Cent Res Rep 9(4): 314-344

Steele JH (1998) Regime shifts in marine ecosystems. Ecol Appl 8:S33-S36

Stergiou KI, Karpouzi VS (2002) Feeding habits and trophic levels of Mediterranean fish. Rev Fish Biol Fish 11: 217-254

Teramoto E (1993) Dynamical structure of energy trophic levels. Ecol Model 69:135-147

Tilman D, Knops NJ, Wedin D, Reich P, Ritchie M, Sieman E (1997) The influence of functional diversity and composition on ecosystem processes. Science 277:1300-1302

Tittensor DP, Worm B, Myers RA (2006) Macroecological changes in exploited marine systems. In: Witman JD, Roy K (eds) Marine macroecology. University of Chicago Press, Chicago, IL

Trites AW, Livingston PA, Mackinson S, Vasconcellos MC, Spriner AM, Pauly D (1999) Ecosystem change and the decline of marine mammals in the eastern Bering Sea: testing the ecosystem shift and commercial whaling hypotheses. Fish Cent Res Rep 7(1):1-106

Tudela S, Coll M, Palomera I (2005) Developing an operational reference framework for fisheries management based on a two dimensional index on ecosystem impact. ICES J Mar Sci 62:585-591

Turányi T (1990) Sensitivity analysis of complex kinetic systems. Tools and applications. J Math Chem 5:203-248

US Commission on Ocean Policy (2004) An ocean blueprint for the 21st century. Final report of the US Commission on Ocean Policy to the President and Congress, Washington, DC

Vasconcellos M, Gasalla MA (2001) Fisheries catches and carrying capacity of marine ecosystems in southern Brazil. Fish Res 59:279-295

Vega-Cendejas ME, Arreguín-Sánchez F, Hernández M (1993) Trophic fluxes on the Campeche Bank, México. In: Christensen V, Pauly D (eds) Trophic models of aquatic ecosystems. ICLARM Conf Proc 26:206-213

Velasco Canziani G (2004) Modelo ecotrófico da plataforma continental do sul do Brasil e cenários de exploração pesqueira da anchoíta (Engraulis anchoita) e o peixelanterna (Maurolicus stehmanii). PhD thesis, Fundação Universidade Federal do Rio Grande

Vivekanandan E, Srinath M, Pillai VN, Immanuel S, Kurup KN (2003) Trophic model of the coastal fisheries ecosystem of the southwest coast of India. In: Silvestre G, Garces L, Ahmed M, Stobutzki I and others (eds) Assessment and management of tropical coastal fisheries in developing Asian countries. ICLARM Conf Proc 26: 281-298

Walters CJ, Martell SJD (2004) Harvest management for aquatic ecosystems. Princeton University Press, Princeton, NJ

Walters CJ, Christensen V, Martell SJD, Kitchell JF (2005) Single-species versus ecosystem harvest management: ecosystem structure erosion under myopic management. ICES J Mar Sci 62:558-568

Worm B, Duffy JE (2003) Biodiversity, productivity and stability in real food webs. Trends Ecol Evol 18:628-632

Worm B, Myers RA (2003) Meta-analysis of cod-shrimp interactions reveals top-down control in oceanic food webs. Ecology 84(1):162-173

Zeller D, Freire K (2001) A preliminary North-east Atlantic marine ecosystem model: Faeroe Islands and ICES area Vb. In: Guénette S, Christensen V, Pauly D (eds) Fisheries impacts on North Atlantic ecosystems: models and analyses. Fish Cent Res Rep 9(4): 207-212 
Appendix 1. Local sensitivity analysis of the L index

In order to explore the propagation of uncertainty of each of the input variables ( $P P R, P_{1}, T E$ and $\mathrm{TL}_{c}$ ) to the value of the $\mathrm{L}$ index, analytical and numerical sensitivity analyses were carried out (Saltelli et al. 2000a). Absolute local sensitivity $s_{\mathrm{L}, j}$ is defined as the first order derivative of the index $\mathrm{L}$ with respect to the input variable $\left(j=\mathrm{PPR}, \mathrm{P}_{1}, \mathrm{TE}, \mathrm{TL}_{\mathrm{c}}\right)$ and is an approximation of the absolute change of the index due to a small change on the input variable's value (Saltelli et al. 2000b). Relative sensitivities $\left(\tilde{\mathrm{S}}_{\mathrm{L}, j}\right)$, obtained by multiplying absolute sensitivity for the nominal value of the input variable and dividing by the output variable (the L index), represent the percentage change in the index due to a $1 \%$ change in the variable, simplifying the comparison among sensitivities of different input variables (Saltelli et al. 2000b). Therefore, sensitivities express the error in the output variable ( $\mathrm{L}$ index) due to the error in the input variables and have a powerful role in uncertainty analysis (Turányi 1990).

In general, sensitivities are functions of the input variables. Thus, they are estimated for nominal values chosen to be representative of the ranges commonly observed. Here, nominal values are chosen as $\mathrm{PPR}^{*}=70 \mathrm{gC} \mathrm{m}^{-2} \mathrm{y}^{-1}, \mathrm{P}_{1}{ }^{*}=$ $200 \mathrm{gC} \mathrm{m}^{-2} \mathrm{y}^{-1}, \mathrm{TE}^{*}=10 \%$ and $\mathrm{TL}_{\mathrm{c}}{ }^{*}=2.5$. Results show that PPR and $\mathrm{P}_{1}$ have an opposite influence on the $\mathrm{L}$ index and that their relative sensitivity is constant (Table A1). Thus, the L index does not depend on the chosen nominal values $\mathrm{PPR}^{*}$ and $\mathrm{P}_{1}{ }^{*}$. Although a first glance at the relative sensitivity shows that TE has non-linear effects on the $\mathrm{L}$ index, in practice, it is very close to linearity and almost constant at different values of TE (this was proven with the numerical sensitivity application as well). Conversely, the sensitivity of the $\mathrm{L}$ index due to errors in $\mathrm{TL}_{c}$ appears to be linear, as can be seen from relative sensitivity formulation, with sensitivity proportional to values of $\mathrm{TL}_{\mathrm{c}}$ with the coefficient $\ln (\mathrm{TE})$. This shows the high changes in sensitivity due to changes in $\mathrm{TL}_{c}$. Therefore $\mathrm{TL}_{c}$ appears to be the most sensitive input variable in the $\mathrm{L}$ index formulation: a $1 \%$ change in its value produces the highest fractional change in L $(5.756 \%)$.

Table A1. Local sensitivity analysis applied to the $\mathrm{L}$ index. Absolute and relative sensitivities are calculated for nominal values of input parameters $\left(\mathrm{PPR}=\right.$ primary production required to sustain fishery; $\mathrm{P}_{1}=$ production at first trophic level; $\mathrm{TE}=$ transfer efficency; $\mathrm{TL}_{\mathrm{c}}=$ trophic level of catches) as reported in the second column. Generally, sensitivities depend on parameter reference value used, however, it should be noted that relative sensitivity due to PPR and $\mathrm{P}_{1}$ are constant

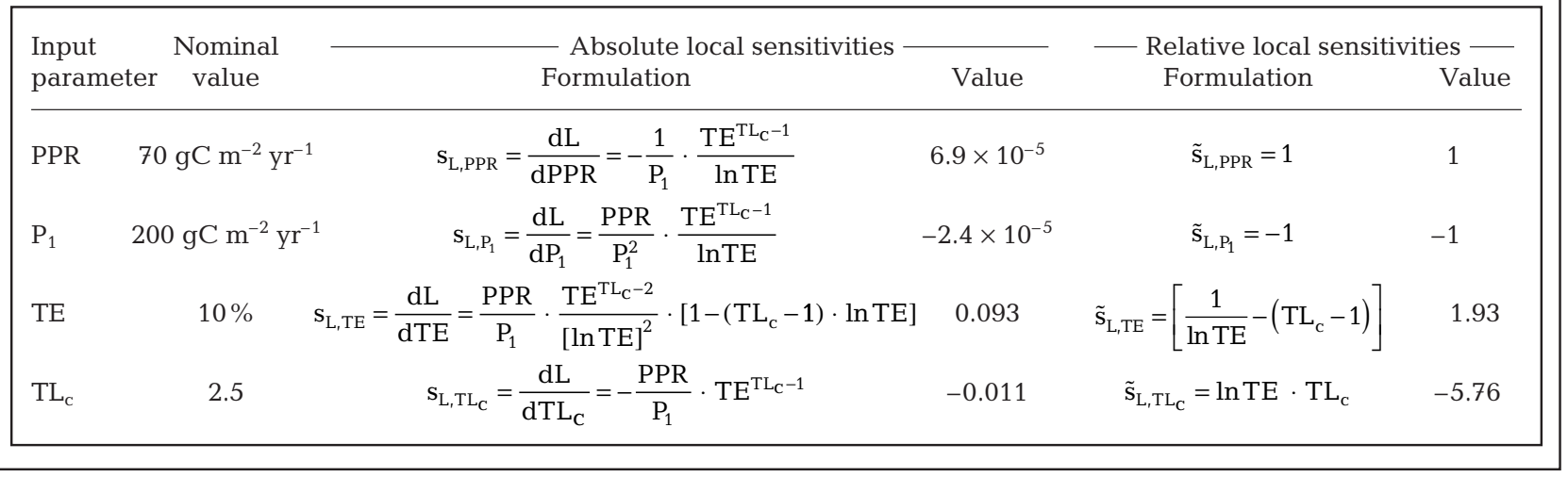

Appendix 2. Transfer efficiency for ecosystem types

Table A2. Summary statistics of transfer efficiency (TE) estimated for ecosystem type on the basis of model data sets

\begin{tabular}{|lccccccccccc|}
\hline & $\mathrm{N}$ & Mean & SE & Median & Mode & SD & Variance & Range & Min & Max & Chosen value \\
\hline $\begin{array}{l}\text { Temperate shelves } \\
\text { and seas }\end{array}$ & 39 & 14.25 & 0.97 & 13.7 & 14.3 & 6.03 & 36.33 & 34.59 & 3.5 & 38.1 & 14 \\
$\begin{array}{l}\text { Tropical shelves } \\
\text { and seas }\end{array}$ & 21 & 10.32 & 0.80 & 9.7 & 13.5 & 3.66 & 13.39 & 12.60 & 5.2 & 17.8 & 10 \\
$\begin{array}{l}\text { Coastal areas } \\
\text { and coral reefs }\end{array}$ & 13 & 12.91 & 1.19 & 13.0 & - & 4.30 & 18.50 & 13.80 & 6.8 & 20.6 & 13 \\
$\begin{array}{l}\text { Upwellings } \\
\text { Lagoons }\end{array}$ & 9 & 5.09 & 0.52 & 4.0 & 3.9 & 1.56 & 2.44 & 4.30 & 3.6 & 7.9 & 5 \\
Total & 9 & 10.97 & 1.05 & 10.8 & - & 3.16 & 9.96 & 9.10 & 6.4 & 15.5 & 11 \\
a Characteristic value of TE for ecosystem type is chosen between mean value for all ecosystems. Chosen values are rounded \\
at the proximate integer according to the average SE observed
\end{tabular}

